This item was submitted to Loughborough's Research Repository by the author.

Items in Figshare are protected by copyright, with all rights reserved, unless otherwise indicated.

\title{
A bibliometric study of taxonomic botany
}

PLEASE CITE THE PUBLISHED VERSION

PUBLISHER

Loughborough University

LICENCE

CC BY-NC-ND 4.0

REPOSITORY RECORD

Walton, Christopher. 2011. "A Bibliometric Study of Taxonomic Botany". Loughborough University. https://hdl.handle.net/2134/12331. 


\title{
A BIBLIOMETRIC STUDY OF TAXONOMIC BOTANY
}

\author{
C. J. Walton
}

A Master's Dissertation

submitted in partial fulfilment of the requirements for the award of the Master of Science Degree at

Loughborough University

August 2011

Supervisor: Prof. A. Morris

Dept. of Information Science

Copyright $(\mathrm{C}: \quad$ C. J. Walton, 2011 


\section{Abstract}

WALTON, C. J.

A Bibliometric study of taxonomic botany / C. J. Walton. - Loughborough : Loughborough University, 2011. — v, 59 p. ; cm. — Dissertation (M.Sc.) Loughborough Univ., Dept. of Information Science, 2011. — Includes bibliography and index.

1. Bibliometrics - botanical literature. 2. Bibliographical citations. 3. Botanydocumentation

Aims - The aims were: to investigate the citation-patterns of monograph books in taxonomic botany (looking mainly at publications and publishers, and the age of current literature); to provide information for collections management and reference services in libraries that hold botany materials.

Method-454 citations were collected from 47 botanical monographs; Impact Factors of journals based on these citations were calculated and compared with conventional Impact Factors from ISI Web of Science; age-distributions of citations were drawn up; other analyses were also carried out.

Results-A small Bradfordian core of highly-cited journals was established; monograph Impact Factors were not useable; the important publishers of monograph books were identified; monographs were more often cited than journal articles; older materials were more important than in other sciences; monographs were used by botanists for current awareness purposes; coverage of botanical journals by citation indexes was inadequate.

Conclusions-Librarians should: note the core botanical journals identified here; note the importance of British journals to British botanists; continue to acquire botanical monographs and to retain older materials; display new botanical monographs prominently and include them in current awareness services.

Problems - The small size of the sample means that results were merely indicative. Further studies should: take larger samples; look at citations in journal articles, theses, conference proceedings, etc.; look at citations made over several years.

Originality-The bibliometrics of taxonomic botany have previously been little studied; likewise citations from monographs. Some of the bibliometric methods of J. M. Cullars were applied to botanical literature. 


\section{Table of contents}

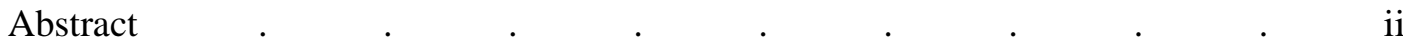

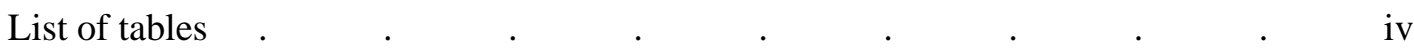

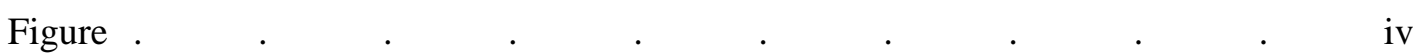

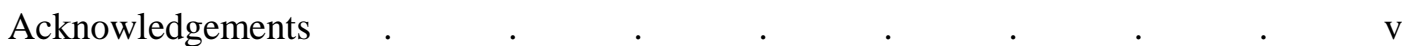

§1. Introduction $\quad . \quad$. $\quad . \quad$.

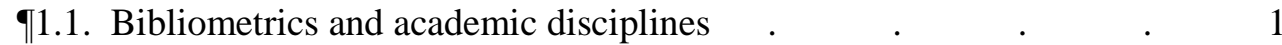

I1.2. The history and nature of research in taxonomic botany $\quad$. $\quad$. 1

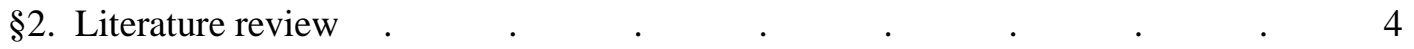

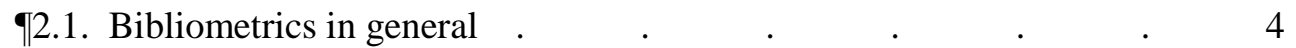

II2.1.1. Descriptive bibliometrics $\quad . \quad$. $\quad . \quad$. $\quad$. 4

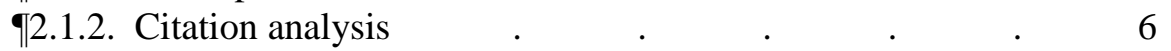

I2.1.3. The meaning of citations $\quad$. $\quad$. $\quad$. $\quad$. $\quad 7$

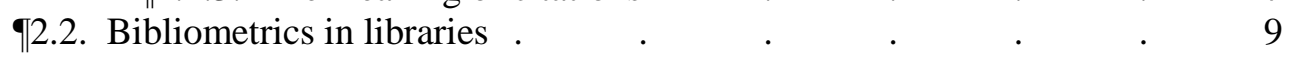

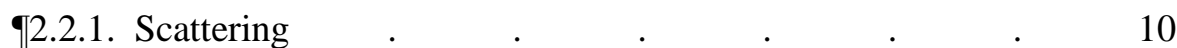

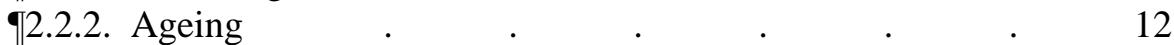

II2.2.3. Impact $\quad . \quad$. . . . . . . . . . 14

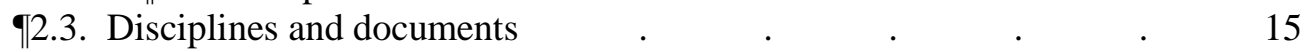

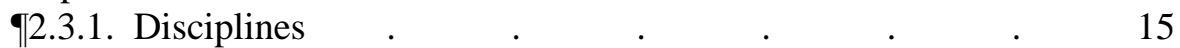

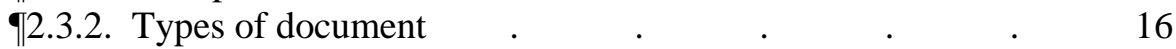

I2.3.3. Bibliometrics and taxonomic botany . . . . $\quad$. 17

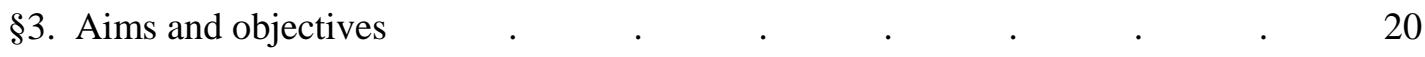

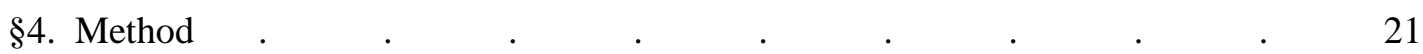

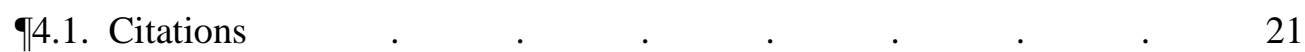

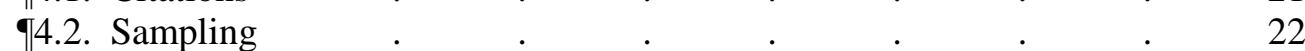

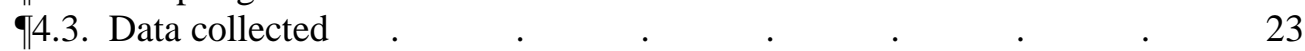

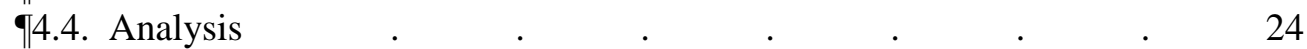

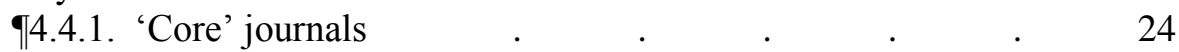

II4.4.2. Major publishers . . . . . . . . 24

914.4.3. Botanical monographs and botanical journals compared . 25

g[4.4.4. Current documentation and changes in its use over time . 25

§5. Results . . . . . . . . . . . . . . . 26

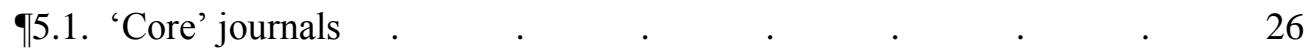

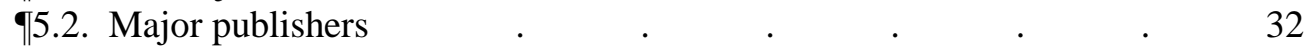

I55.3. Botanical monographs and botanical journals compared . $\quad$. 33

I5.4. Current documentation and changes in its use over time . $\quad$. $\quad 34$

95.5. Other results . . . . . . . . . . . . . 39

I55.5.1. Countries and languages of publication . $\quad . \quad 39$

II5.5.2. Important journals for British botanists . . . . . 43

I55.5.3. Citation indexes and taxonomic botany . . . . 43

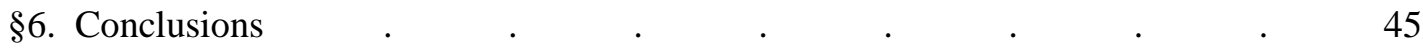

I6.1. General remarks and recommendations $\quad . \quad$. $\quad . \quad$. $\quad . \quad$. 45

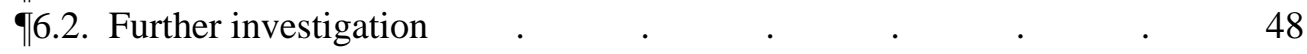

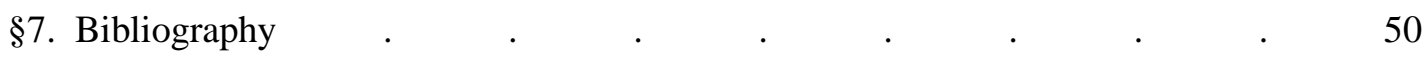

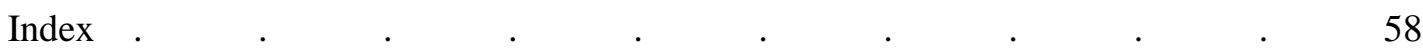




\section{List of tables}

Table 1: 10-year monograph Impact Factors . $\quad$. $\quad$. $\quad$. $\quad$. 27

Table 2: Conventional Impact Factors $\quad . \quad$. $\quad . \quad$. $\quad . \quad$. $\quad . \quad 28$

$\begin{array}{llllllllllll}\text { Table 3: Journal productivity of cited articles } & \text {. } & \text {. } & \text {. } & & & 29\end{array}$

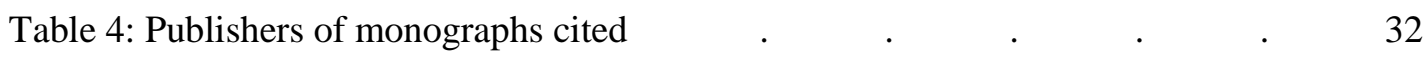

Table 5: Cited document type $\quad . \quad \ldots \quad$.

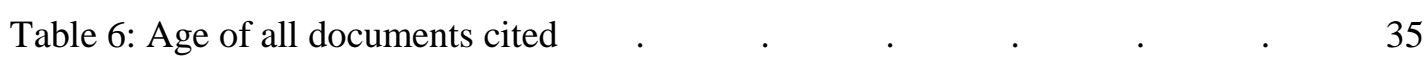

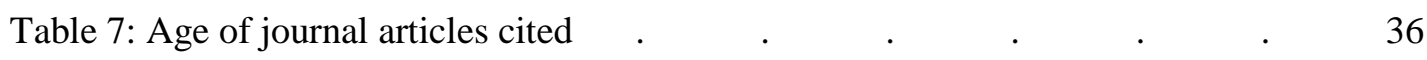

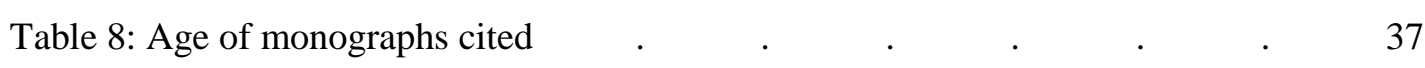

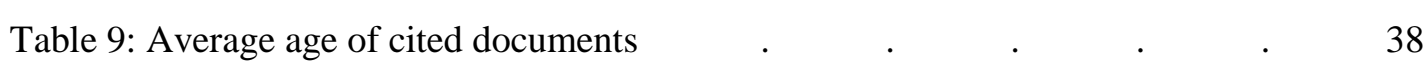

Table 10: Country of publication of citing monographs $\quad . \quad$. $\quad$. $\quad$. $\quad 39$

Table 11: Country of publication of cited documents $\quad . \quad$. $\quad . \quad$. $\quad$. 40

Table 12: Language of citing monographs $\quad$. $\quad . \quad$. $\quad . \quad$. $\quad . \quad 41$

Table 13: Language of cited documents . $\quad . \quad$. $\quad . \quad$. $\quad . \quad$. 42

Table 14: Journals cited in monographs published in Great Britain 43

Figure

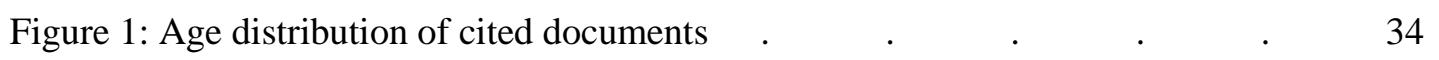




\section{Acknowledgements}

It is a pleasure, as well as a duty, for me to acknowledge the help that I have received. First of all I thank my supervisor, Professor Anne Morris: her guidance in the unfamiliar world of information science research has been invaluable, and her prompt and constructive advice has made the whole project run very smoothly. Secondly, I thank the staff at the Library of the Royal Botanic Gardens, Kew - in particular Mr. Craig Brough, who arranged for my data-collecting visit and allowed me easy access to the books; and also Ms. Anne Griffin, Ms. Anne Marshall and Mr. Steve Piper, for their usual indefatigable camaraderie, as well as for the use of a computer. Finally I thank Mrs. A. M. Catterall, Librarian at the Sherardian Library of Plant Taxonomy, University of Oxford, for letting me into her Library at very short notice. This dissertation has depended upon the assistance of all of these people; any errors in it are, of course, my own. 
...his prestige was such that even a joke from Rutherford's mouth was apt to become a dogma in lesser men's minds. No very young physicist could be totally unaffected by his famous crack: 'All science is either physics or stamp collecting'...

-P. M. S. Blackett. ${ }^{1}$

\section{§1. Introduction}

\section{II1.1. Bibliometrics and academic disciplines}

Citation studies of whole disciplines (as opposed to those of the output of individual scholars or of particular journals) have tended to concentrate on the mathematical sciences, engineering and medicine; studies have also been carried out on various social sciences, and more recently even on some humanities disciplines; botany, however, has been relatively neglected. This study is intended to investigate the bibliometrics of taxonomic botany as a discipline, to provide indicative data from which tentative (but hopefully practical) conclusions may be drawn, and to begin to remedy the comparative lack of research in this field. 'Taxonomic botany' is taken to mean that branch of botany which distinguishes and describes species and other groupings ('taxa') of plants, and which names them and classifies them in relation to each other; it is also known as 'systematic botany' or 'plant systematics'. It is the basis of much of the rest of the discipline of botany, and many botanists work in it.

\section{II1.2. The history and nature of research in taxonomic botany}

The taxonomical study of plants began in antiquity with the Greek philosopher Theophrastus $\left(4^{\text {th }}-3^{\text {rd }}\right.$ c. BC), who investigated and ordered plants according to their mutual resemblances and shared characteristics. His books De Historia plantarum and De Causis plantarum have survived in MS. His example was not followed, however, and later writers had more utilitarian interests: Roman authors like Cato and Columella dealt mainly with agricultural crops; and the Greek author Dioscorides investigated medicinal plants-his De Materia

${ }^{1}$ In: Birks, J. B. (ed.). Rutherford at Manchester. London : Heywood and Company, 1962, p. 108. 
medica was in continuous use throughout later Antiquity and the Middle Ages. No appreciable progress was made in the Middle Ages, but after the Renaissance botany revived along with the other sciences. By the seventeenth century botanists were in the habit of attaching definite names (in Latin) to what they regarded as distinct types of plant, but there was no shared system of naming or of distinguishing.

As a result, there were sometimes many different names for the same type of plant. In the eighteenth century the Swedish botanist Carl Linnaeus (1707-1778) worked out systems for describing plants, for classifying plants, and also for naming both plants and animals. The latter is the 'binominal system' and is still with us: Homo sapiens and Aloe vera are familiar examples of it. His system of classification was strictly descriptive, and was based on the number and arrangement of pistils and stamens in the flowers of the plant under investigation (it was therefore called the 'sexual system'). This was a great step forward: the principle that plants should not merely be identified but identified according to a system was firmly established. The problem with Linnaeus's system was that, since it took as its sole criterion the internal arrangement of a plant's flowers, it put some types of plant together which were markedly different in other respects, and separated others which were markedly similar. It is one of the oddities of the history of science that Linnaeus, having such a firm grasp of identification and description, must have seen the incongruities that resulted from his classificatory system - and yet he stuck to it. ${ }^{2}$ The French botanists Michel Adanson (1727-1806) and Antoine Laurent de Jussieu (1748-1836) established the practice of systematic classification on the basis of a variety of characteristics (the 'natural system'). ${ }^{3}$ Broadly speaking, botanical classification and description have gone hand-in-hand ever since, and the taxa that they produce have tended to be corroborated by the subsequent findings of plant physiology, biochemistry, and ultimately genetics (which of course shows definitively how groups of plants are related to each other by heredity).

However, once a particular type of plant has been identified, distinguished, named and classified, this may not be the end of the story. A new species may be discovered in a remote corner of the world; or there may be a new discovery in physiological or genetic research - such discoveries may show that the present taxonomical view of this plant is wrong, and needs to be changed. In this case a botanist must carry out a 'revision' of this type of plant, and this means carefully working over previous research to make sure that any rearranging that has to be done takes this previous research into account. The naming and

\footnotetext{
${ }^{2}$ Morton, A. G. History of botanical science: an account of the development of botany from ancient times to the present day. London: Academic Press, 1981. pp.259-276.

${ }^{3}$ Morton. History of botanical science. pp.311-313.
} 
renaming of species, in particular, follows a very elaborate and conservative set of rules. ${ }^{4}$ This means that all progress in taxonomic botany is always accompanied by research into previous results - sometimes decades or even centuries old — which sets it very much apart from sciences like chemistry and physics: in these disciplines all but the most epoch-making research quickly ceases to be used. In other words, botanical research is less concentrated into what Price called a 'research front' (see below, 1 22.2.2.). This is the first thing that makes taxonomic botany interesting from a bibliometric point of view.

The second thing (related to the first) is the greater importance which taxonomic botany attaches to the publication of work in monograph books. The 'revisions' mentioned above, if they are of particularly large or complicated taxa, are often published as books; the other distinctive genre of botanical book is the 'flora'. A flora is effectively a hand-list of all the species of plant found in a particular geographical region, each presented with a taxonomic description (and sometimes an illustration), and organized according to its taxonomic classification. Compiling a flora requires a great deal of investigative field work, but again prior research must also be consulted, for a number of reasons: it may be that what the fieldworker has taken to be a newly-discovered species has in fact already been discovered but has somehow not been recorded properly (e.g. mis-named or mis-classified); or that a species that had been recorded before is now more or less common than it used to be (or indeed is now extinct); or simply that previous floras dealing with the region are useful guides for new research. (We have already seen the connexion of taxonomy with physiology and genetics; here we see its connexion with ecology.) Floras and revisions embody much of the most valuable and significant botanical research, and therefore both must be of bibliometric interest.

\footnotetext{
${ }^{4}$ International code of botanical nomenclature [online]. <http://ibot.sav.sk/icbn/main.htm> [2011], [accessed 04.04.2011].
} 


\section{§. Literature review}

\section{II2.1. Bibliometrics in general}

Bibliometric literature, consisting of bibliometric studies and related works of theory and criticism, is very large. This survey is therefore highly selective, and the usefulness of the literature has been judged by how far its concerns correspond to those of the present study. Readers with a special interest in bibliometrics must therefore not be surprised if what seems to them an important feature of their discipline is not dealt with, or is dealt with only briefly: for instance, methods for assessing the output of individual scientists, or of academic institutions, are not discussed, because this study does not aim to make such an assessment. On the other hand, it will be necessary to discuss some literature whose methods or conclusions are ultimately judged to fall outside the limited scope of this study.

\section{I2.1.1. Descriptive bibliometrics}

Quantitative and statistical methods for describing and analysing whole bodies of literature have existed since the early twentieth century, and the bibliometric literature itself can be viewed in terms of the progressive development of these methods, and reactions to them. There are two main approaches to bibliometric description and analysis, which in practice often overlap: the first is purely bibliographical, and the second analyses citations. In the former, a body of documents is selected and its bibliographic features counted-authors, titles, numbers of pages, places of publication, type of publication (e.g. book, journal article, 'grey literature'), and so on - and the resulting data may be tabulated, cross-tabulated, and 
analysed. Nicholas and Ritchie call this 'descriptive' bibliometrics. ${ }^{5}$ Bibliometric reports from the DISISS project (Design of Information Systems in the Social Sciences), which was carried out in the late 1970s, give striking examples of the level of detail which descriptive methods can go into when a sufficiently large body of literature is studied. (Of course the DISISS studies also analysed citations, but the point stands. $)^{6}$

At an early date the results of descriptive methods were reduced to mathematical 'laws': the two most important of these are Lotka's law and Bradford's law. Lotka's law is a mathematical formula which states how many researchers in a particular academic field are likely to have published a given number of journal articles. Essentially, the number of authors who have published $\mathrm{x}$ papers is inversely proportional to $\mathrm{x}^{2}$ : in other words, only a very small minority of researchers in a field publish even a handful of papers each (most publish only one). ${ }^{7}$ Bradford's law expresses a similar inverse square relationship, this time between academic journals and articles in those journals on a particular subject. Bradford wanted to quantify how relevant particular journals were or were likely to be to particular fields of study, and to do this he worked out how densely 'scattered' relevant articles were throughout a large body of journals. He concluded that, in respect to a particular subject, journals could be arranged in ranks according to relevance. The first rank, or 'core', would be a relatively small number of journals each containing a high proportion of relevant articles. Subsequent ranks could be determined, each with more journals than the last, but journals that contained steadily decreasing proportions of relevant articles. For each rank, the product of the number of journals and the number of relevant articles was more or less constant. $^{8}$ It has since been shown that Bradford's and Lotka's distributions are fundamentally equivalent in mathematical terms, and are related to other skewed statistical distributions known in other fields of study (such as Pareto's distribution in economics). The precise meaning and character of these 'laws' have been debated in detail since, and will be returned to: for the time being it is enough to note their importance-Bradford's method is particularly important for the present study.

\footnotetext{
${ }^{5}$ Nicholas, David, and Ritchie, Maureen. Literature and bibliometrics. London : Clive Bingley, 1978, pp.38-93.

${ }^{6}$ Line, Maurice B. The Structure of social science literature as shown by citations. [Bath] : Bath University, 1979.

Nicholas, David, Ritchie, Maureen, and Ritchie, Adrian. Literature usage and interrelationships in the social sciences as shown by citations in monographs. [London] : Polytechnic of North London, 1978.

${ }^{7}$ Lotka, A. J. 'The Frequency distribution of scientific productivity.' Journal of the Washington Academy of Sciences, 1926, 16 (12), pp.317-323, cited in: Andrés, Ana. Measuring academic research: how to undertake a bibliometric study. Oxford : Chandos, 2009, pp.23-30.

${ }^{8}$ Bradford, S. C. Documentation. $2^{\text {nd }}$ ed. reprint. [Ann Arbor, Michigan] : University Microfilms, 1971, pp.144-159.

${ }^{9}$ Fairthorne, Robert A. 'Empirical hyperbolic distribution (Bradford-Zipf-Mandelbrot) for bibliometric description and prediction.' Journal of documentation [online], 2005, 61 (2), pp.171193. <http://www.emeraldinsight.com>, [accessed 12.04.2011].
} 


\subsubsection{Citation analysis}

Citation analysis is the second main approach to bibliometrics. This is where bibliographical references in a selected body of documents are collected, and the documents to which they refer are then quantified, compared and contrasted in terms of the references made to them (or citations of them). ${ }^{10}$ This was made possible on a large scale when Garfield set up his Science Citation Index in 1960. The ISI Web of Science (as the SCI is now known) is a database of journal articles, indexed according to other articles which cite them, rather than by subject. The great advantage of this as an indexing system is that it can be completely automated. The presupposition upon which it rests is that the relationship of one article to another established by a citation is a sufficient surrogate for a subject descriptor - in other words, that, if one article cites another, the two have subject matter in common. ${ }^{11}$ The question of the meaning of citations will be returned to later: the important thing to note at this stage is that the $S C I$, by collecting citations to documents automatically, has made citation analysis enormously easier.

Garfield himself has written extensively on the statistics that it is possible to compile, the uses to which they may be put, and problems of interpretation. ${ }^{12}$ Most obviously, simple counts can be made of citations to articles by a particular author, articles in a particular journal, and so on - the problem with this is that older authors or bigger journals get bigger counts purely on the basis of their output. To help remedy this Garfield devised a measure called the 'Impact Factor' ('I.F.') as a way of ranking journals by citations. It is calculated as follows:

$$
\text { Impact Factor of journal } x=\frac{\begin{array}{c}
\text { no. of citations in articles in all journals published in year } c \\
\text { of articles published in journal } x \text { in years } a \text { and } b
\end{array}}{\text { no. of research articles published in journal } x \text { in years } a \text { and } b}
$$

It is effectively the average number of citations received by each article published recently in a given journal-it therefore corrects for the number of articles in each volume of the journal,

\footnotetext{
${ }^{10}$ The distinction between 'reference' and 'citation' is made clear by Price, Derek J. de Solla. 'Citation measures of hard science, soft science, technology, and nonscience.', in: Nelson, Carnot E., and Pollock, Donald K (edd.). Communication among scientists and engineers. Lexington, Massachusetts : D.C. Heath, 1970, p.7.

${ }^{11}$ This assumption is made explicit by Price, Derek J. de Solla. 'Networks of scientific papers.' Science [online], 1965, 149 (3683), pp.510-515. 〈http://www.sciencemag.org>, [accessed 01.02.2011].

${ }^{12}$ Garfield, Eugene. Citation indexing: its theory and application in science, technology and humanities. New York : John Wiley and Sons, 1979.

- Essays of an information scientist. Philadelphia : ISI Press, 1977-1981 (this consists largely of articles reprinted from Current contents, a newsletter published by Garfield alongside the SCI in its pre-electronic form).

and Sher, I. H. 'New factors in the evaluation of scientific literature through citation indexing.' American documentation [online], 1963, 14 (3), pp.195-201. <http://web.ebscohost.com>, [accessed 18.04.2011].
} 
and for the age of the journal. 'Recently' means 'in the previous two years' - this is the socalled 'citation window'. The I.F. has been widely used in the past few decades and has become controversial, owing partly to how it is calculated and partly to how it is interpreted and used. ${ }^{13}$

Other methods of investigating and measuring citations have been developed since the appearance of the SCI, such as 'bibliographic coupling', 'co-citation analysis', the 'immediacy index', 'obsolescence', 'half-life' and many others. ${ }^{14}$ In recent decades bibliometrics have moved away from assessing documentation as such towards assessing the researchers and institutions that produce it, and new measures have been devised with this in mind. ${ }^{15}$ The ' $h$-index' is a simple measure which has been widely adopted and discussed since it was first proposed by Hirsch in 2005 . It is determined as follows: all the publications of a particular author are assembled, and are ranked in descending order according to the number of times each has been cited; $h$ is then the number of publications whose citation-counts are at least as great their respective ranks. ${ }^{16}$ This is taken to be a measure both of output and of impact, and one which to some extent normalizes scores between researchers who might otherwise be incomparable (such as those at different stages in their career); it also minimizes the effect of unusually highly-cited papers, which might unduly skew a bare count of citations. In 2006 Egghe proposed the ' $g$-index' as a modification of $\mathrm{h}$. Articles are ranked in the same way as for $\mathrm{h}$, but $\mathrm{g}$ is found by determining the number of papers which taken together receive at least $g^{2}$ citations. The purported advantage of this is that if highly ranked papers continue to receive citations, this will be reflected in the index without unduly skewing it. ${ }^{17}$

\section{I2.1.3. The meaning of citations}

Garfield, Price and many other early citation analysts thought that the more often a work was cited, the more important, influential, valuable and correct that work was likely to be. This assumption is clear even in some of Garfield's earliest research—but it is only fair to

\footnotetext{
${ }^{13}$ For a summary of the I.F., see Andrés, Ana. Measuring academic research: how to undertake a bibliometric study. Oxford : Chandos, 2009, pp.84-95.

${ }^{14}$ Andrés, Measuring academic research provides a good overview of many of these measures.

${ }^{15}$ Good examples of this shift in interest can be found in: Borgman, Christine L. (ed.). Scholarly communication and bibliometrics. Newbury Park, California : SAGE, 1990, and Vinkler, Péter. The Evaluation of research by scientometric indicators. Oxford : Chandos, 2010.

${ }^{16}$ Hirsch, J. E. 'An Index to quantify an individual's scientific output.' Proceedings of the National Academy of Sciences of the United States of America [online], 2005, 102 (46), pp.16569-16572. $<$ http://www.ncbi.nlm.nih.gov/pmc/>, [accessed 12.04.2011].

${ }^{17}$ Egghe, Leo. 'Dynamic $h$-index: the Hirsch index in function of time.' Journal of the American Society for Information Science and Technology [online], 2006, 58 (3), pp.452-454. <http://onlinelibrary.wiley.com/>, [accessed 13.04.2011]. - 'Theory and practise [sic] of the g-index.' Scientometrics [online], 2006, 69 (1), pp.131-152. $<$ http://www.springerlink.com>, [accessed 13.04.2011].
} 
acknowledge that he has long accepted that the precise relationship between the quality of a piece of work and the number of citations that it receives is not a simple one. ${ }^{18}$ The view that there is nevertheless a connexion is known as the 'normative' view of citation, since it accepts that the norms of citation - that scholars should cite any prior research that is relevant and important in some way to their own - are applied in practice. During the 1970s and 1980s the opposite view grew up: that in practice individual scholars make individual citations for a variety of reasons which may have nothing to do with the importance or quality or relevance of the document cited; or (worse still) they may make no citation at all where one is required. This view has been described as the 'sociological' or 'socialconstructivist' view-Cronin has been an important advocate. ${ }^{19}$ A corresponding strand of research grew up studying the motivations for citation, either by careful inspection of the contexts in which references were made, of the documents cited in relation to the citing documents, or even by interviewing the citing authors themselves. These interpretative studies often resulted in 'typologies' of citations: sets of classes to which individual citations could be assigned to aid interpretation. Even in 1984 the number of these 'typologies' was becoming unmanageable, and they have continued to proliferate since. ${ }^{20}$ The sociological view is basically at odds with the idea that the measurement of citations can be used to show anything real, since, if no two citations are made for the same reason, aggregating them is meaningless. The most extreme scepticism can be found in the work of MacRoberts and MacRoberts, who showed up the highly subjective and deficient citation-habits of a number of researchers. ${ }^{21}$

However, most citation analysts do not go so far as this sort of scepticism; indeed the question of how to 'reconcile' the sociological view with the normative view has often been asked (without ever really having been answered). The sociological view has in any case been on the wane in recent years as bibliometric research has moved over to assessing scientific output. Baird and Oppenheim have reasserted the reliability of citation analysis on the straightforwardly empirical ground that, whatever may be said about the motives or

\footnotetext{
${ }^{18}$ Garfield and Sher, 'New factors', p.199.

See also: Garfield, Eugene. Citation indexing: its theory and application in science, technology and humanities. New York : John Wiley and Sons, 1979, p.63; pp.240-252.

${ }^{19}$ Cronin, Blaise. The Citation process: the role and significance of citation in scientific communications. London : Taylor Graham, 1984.

${ }^{20}$ Cronin, The Citation process, p. 35.

For later surveys of these interpretations, see: Liu Meng Xiong. 'The Complexities of citation practice: a review of citation-studies.' Journal of documentation [online], 1993, 49 (4), pp.370-408, <http://www.emeraldinsight.com>, [accessed 08.04.2011], and

Bornmann, Lutz, and Daniel, Hans-Dieter. 'What do citation counts measure? A review of studies on citing behavior [sic].' Journal of Documentation [online], 2008, 64 (1), pp.45-80.

<http://www.emeraldinsight.com>, [accessed 08.04.2011].

${ }^{21}$ MacRoberts, M. H., and MacRoberts, B. R. 'Problems of citation analysis: a critical review.' Journal of the American Society for Information Science [online], 1989, 40 (5), pp.342-349. <http://web.ebscohost.com>, [accessed 12.04.2011].
} 
habits of researchers, citation-indices correlate closely with almost any other measure of the quality or impact of research. ${ }^{22}$ This view seems to have received more or less guarded general approval in recent years-what is usually stressed is that the larger the sample, the better; ${ }^{23}$ and that bibliometric indices should be thoughtfully assessed and should not be used alone when important decisions are being made: "citations have to be treated carefully, and the interpretation of indices based on citation must be conservative." ${ }^{24}$ Subject to these qualifications, it is a basic assumption of the present study that citations do indeed indicate the value and usefulness of the works they cite to the authors who cite them; and by extension that citations can be taken as a measure of the worth and importance of academic research.

\subsection{Bibliometrics in libraries}

What citations mean is distinct from, but obviously related to, what they may be used for. The present study is concerned with using bibliometrics to help deal with library problems, and perhaps the most important work in this area was done by Maurice Line (who was himself a librarian). His studies (mostly from the 1970s) were marked by a concern for a clear understanding of what specific facts particular bibliometric data really indicated; to what practical uses they might legitimately be put; and how far they might have to be qualified by other considerations. ${ }^{25}$ His interest in the interpretation of bibliometric data was different from the sociological concerns mentioned above: he investigated what citation data said about the use of the documents that they referred to, rather than what such data said about the value of those documents. He also scrutinized the internal logic of some of the citation-indices that had been developed on the back of the SCI, including 'obsolescence'. Line's scepticism about the value of bibliometrics in libraries did not prevent him from undertaking one very large bibliometric study as part of DISISS (see above); even so, his observation that there were few, if any, examples of the successful application of exclusively bibliometric methods to library problems still holds good today. It is after all "highly

\footnotetext{
${ }^{22}$ Baird, Laura M., and Oppenheim, Charles. 'Do citations matter?' Journal of information science [online], 1994, 20 (1), pp.2-15. <http://online.sagepub.com>, [accessed 07.04.2011].

${ }^{23}$ De Bellis, Nicola. Bibliometrics and citation analysis: from the Science Citation Index to cybermetrics. Lanham, Maryland : Scarecrow Press, 2009, pp.335-337.

Raan, Anthony F. J. van. 'Fatal attraction: conceptual and methodological problems in the ranking of universities by bibliometric methods.' Scientometrics [online], 2005, 62 (1), pp.134-135.

<http://www.springerlink.com>, [accessed 11.04.2011].

${ }^{24}$ Andrés, Measuring academic research, p.97.

See also: Moed, Henk F. Citation analysis in research evaluation. Dordrecht : Springer, 2005, p.4; p.80.

${ }^{25}$ The classic is: Line, Maurice B., and Sandison, A. ' 'Obsolescence' and changes in the use of literature over time.' Journal of documentation [online], 1974, 30 (3), pp.283-350 (esp. pp.303-11; 318-321). <http://www.emeraldinsight.com>, [accessed 02.02.2011].

An overview of Line's work is given by: Meadows, A. J. 'A Practical line in bibliometrics.'

Interlending and document supply [online], 2005, 33 (2), pp.90-94.

<http://www.emeraldinsight.com>, [accessed 14.04.2011].
} 
improbable that citations reflect closely uses in any individual library." ${ }^{26}$ This is a problem which must be faced squarely by anyone seeking to put bibliometric data to use in libraries. Line's scepticism has been echoed by other librarians; ${ }^{27}$ but some have expressed cautious optimism about the usefulness of bibliometrics. ${ }^{28}$ Moreover, at least one study has shown that patterns of citations made by readers in particular libraries reflect what materials those libraries provide access to. ${ }^{29}$ Bibliometrics has found a place in standard modern textbooks on information needs-assessments and on collection management. ${ }^{30}$ Nicholas and Ritchie preface their study with the observation that a bibliometric approach

can be used in small and manageable ways, by individuals, to improve some part of a library or information service. Herein lies its greatest appeal: the most useful applications start small. ${ }^{31}$

It is in just such a modest hope that this study is carried out.

\section{I[2.2.1. Scattering}

Bradford's theory of 'scattering' of subject-relevant journal articles has already been outlined (see above, I[2.1.1.). Bradford himself intended that it should be applied to the selection of journals to be abstracted and indexed; in libraries the obvious application is to the selection or deselection of stock, especially where the cost of serials subscriptions is becoming unbearable. Journals can be ranked according to certain citation-statistics (say, their I.F.), and a Bradford-type distribution can be obtained; a 'core' of highly-cited journals in a particular field can then be identified, these can be obtained or kept; any which fall outside the 'core' can be ignored or cancelled. ${ }^{32}$ Garfield among others has advocated this

\footnotetext{
${ }^{26}$ Line, Structure of social science literature, p.2.

${ }^{27}$ For instance: Wallace, Danny P. 'A Solution in search of a problem: bibliometrics and libraries.' Library journal [online], 1987, 112 (8), pp.43-47. <http://web.ebscohost.com >, [accessed 14.04.2011].

${ }^{28}$ For instance: Corby, Katherine. 'Constructing core journal lists: mixing science and alchemy.' Portal: libraries and the academy [online], 2003, 3 (2), pp.207-217. 〈http://muse.jhu.ed >, [accessed 12.04.2011].

${ }^{29}$ McDonald, John D. 'Understanding journal usage : a statistical analysis of citation and use.' Journal of the American Society of Information Science and Technology [online], 2007, 58 (1), pp.39-50. <http://web.ebscohost.com>, [accessed 16.06.2011].

${ }^{30}$ Nicholas, David, and Herman, Eti. Assessing information needs in the age of the digital consumer. $3^{\text {rd }}$ ed. London : Routledge, 2009, pp.150-152.

Johnson, Peggy. Fundamentals of collection development and management [online]. $2^{\text {nd }}$ ed. Chicago : ALA, 2009. <http://opac.lboro.ac.uk>, [accessed 17.05.2011], pp.247-248.

${ }^{31}$ Nicholas and Ritchie, Literature and bibliometrics, p.14.

32 The reader will note the shift from Bradford's own procedure of investigating journal articles by subject (i.e. by traditional index-descriptor) to investigating them by citation-we have already discussed the relation of these two things (I2.1.3.). One sometimes finds Garfield constructing a genuine Bradfordian 'core' of journals on a particular subject using citations from another 'core' of citing journals, which have been arbitrarily selected. It is the selection of this arbitrary citing 'core' which should guarantee the subject-relevance of the citations on which the Bradfordian 'core' is based - although the whole procedure seems to beg the question. See: Garfield, Eugene. 'Journal citation studies. 33, Botany journals. Part 1, What they cite and what cites them.' In: Essays of an information scientist. Philadelphia : ISI Press, 1977-1981, vol.4, pp.555-562.
} 
method. ${ }^{33}$ There are, however, practical problems: firstly, a journal whose articles are often cited may not be used very much by readers in a particular library, or, vice versa, a heavily used journal may be very little cited - this may happen with trade journals in areas like engineering, for instance. It could be argued that it is basically wrongheaded to determine a collections policy for a library used mainly by local undergraduates on the strength of the citation habits of academics, most of whom are from entirely other institutions. ${ }^{34}$ Line himself helped to carry out a study comparing citation analyses of journals from the SCI with figures for the use of the same journals by borrowers from the British Library Lending Division (as was). He found that citation and use did not correlate (although later investigation has questioned his findings). ${ }^{35}$

The second problem is that even if citation (as opposed to use) is taken to be a good criterion for judging the desirability of a particular journal, other things must be considered at the same time, namely the cost of the journal (subscription, processing, binding) and the amount of space that it occupies. In other words, the librarian must consider the number of citations per pound spent, or per metre of shelving taken up. Such calculations can become bewildering - although admittedly the problems of binding and shelf space may lessen as more journals are published electronically. ${ }^{36}$ The third problem is that in practice the serials librarian (or whoever is responsible) will probably have a pretty clear idea already of which are the essential journals in a particular subject, and which are not: the problem is in coming to a decision about borderline cases, and here Bradford is of no help. ${ }^{37}$ Finally, it has been shown that, depending on how the subject of an article is construed, Bradford analyses (of the old fashioned type, based simply on subject) can produce very different results based on

This process is made explicit and iterative by: Hirst, Graeme. 'Discipline Impact Factors: a method for determining core journal lists.' Journal of the American Society for Information Science [online], 1978, 29 (4), pp.171-172. <http://web.ebscohost.com>, [accessed 13.04.2011].

${ }^{33}$ Garfield, Eugene. 'Is citation frequency a valid criterion for selecting journals?' Current contents [online], 1972, 13. <http://www.garfield.library.upenn.edu>, [accessed 13.04.2011].

See also: Garfield, Eugene. 'The Mystery of the transposed journal lists: wherein Bradford's Law of Scattering is generalized according to Garfield's Law of Concentration.', in: Essays, vol.1, pp.222223.

${ }^{34}$ De Bellis, Bibliometrics and citation analysis, pp.95-105, notes the limited usefulness of Bradford's law to librarians.

${ }^{35}$ Line, Maurice B. 'On the Irrelevance of citation analyses to practical librarianship.' In: EURIM II: a European conference on the application of research in information services and libraries. London : Aslib, 1977, pp.51-56.

See also: Bensman, Stephen J. 'Urquhart's and Garfield's laws: the British controversy over their validity.' Journal of the American Society for Information Science and Technology [online], 2001, 52 (9), pp.714-724. < http://web.ebscohost.com>, [accessed 13.04.2011].

${ }^{36}$ Line, Maurice B. and Sandison, A. 'Practical interpretation of citation and library use studies.' College and research libraries, 1975, 36 (5), pp.393-396.

Line and Sandison, 'Obsolescence', pp.320-321.

${ }^{37}$ Line, 'Irrelevance', p.51. 
the same journals; most alarmingly, they can result in minority views being entirely suppressed. $^{38}$

Faced with all these problems, the librarian may wonder whether there is any value at all in attempting to determine the scatter of subject-relevant or highly-cited articles across a group of journals. In determining the most important journals for a particular group of readers, circulation statistics and the express wishes of the readers themselves should be taken into account, as well as bibliometric data: the point is to ground decisions on as broad a base of evidence as possible. For instance, as Corby points out, relying merely on circulation statistics is of no use for deciding which journals should be obtained - the particular value bibliometric data is that they can provide information about materials that are not in stock already. ${ }^{39}$ The other possible use for 'core' journal lists which Corby identifies is to help library staff to become acquainted with the collection and its probable uses; by extension, such lists could be useful for dealing with reference questions and for providing information literacy training to new postgraduates, for instance; it may be that more established researchers would also take an interest in such lists.

\section{II2.2.2. Ageing}

The second practical library problem, related to the first, is the question of the ageing of library materials, their supposed 'obsolescence', and how this is reflected in citation-patterns. (As with the question of scattering, so here an underlying problem is how far citation and use coincide.) It was observed soon after the establishment of the SCI that articles in journals tended to cite a higher proportion of other articles which had been published relatively recently; the older the material, the less likely they were to refer to it. Price termed this phenomenon 'immediacy', and devised an index to measure it: Price's Index is the percentage of all the references in a journal (or journals) to materials not more than five years old. If all the journals in a discipline are selected, then the 'immediacy' of that discipline as a whole can be calculated. This is a numerical expression of what Price termed a 'research front': the tendency of scientific activity in a particular field to be concentrated on particular, limited problems. The more pronounced the research front, the more rapidly discoveries are made and communicated, and the more rapidly previous discoveries lose their immediate interest. ${ }^{40}$

This phenomenon, looked at in another way, was termed 'obsolescence' by other scholars, who saw in the gradual waning of references to papers as they got older an analogy with the

\footnotetext{
${ }^{38}$ Nicolaisen, Jeppe, and Hjørland, Birger. 'Practical potentials of Bradford's law: a critical examination of the received view.' Journal of documentation [online], 2007, 63 (3), pp.359-377. <http://www.emeraldinsight.com>, [accessed 12.04.2011].

${ }^{39}$ Corby, 'Constructing core journal lists', pp.212-213.

${ }^{40}$ Price, 'Citation measures', p.10; 'Networks of scientific papers', p.512-515.
} 
decay of radioactive substances: the 'half-life' of journals was calculated to illustrate this. This can be done in two ways. Firstly, one can assemble all the references in the journal under investigation in a particular year, and find their median age: this is the 'citing half-life' of that journal. Alternatively, one can assemble all the references in the whole literature of a given year to articles which have appeared in previous years in the journal under investigation; the median age of the articles thus cited is taken to be the 'cited half-life' of this journal. ${ }^{41}$ The shorter the 'half-life', the more likely it is that the discipline represented by the journal has a 'research front' of the Pricean kind, and of course this is interesting for those studying the workings of scientific research.

To the librarian, on the other hand, quantifiable 'obsolescence' appears to offer a clear criterion for when to dispose of back runs of journals, which often take up valuable shelf space and seem to go unused. The problem with this view, as Line saw, is that it rests on a misunderstanding of the statistics and what they are referring to. 'Obsolescence' and 'citing half-life' essentially express the likelihood that a particular item of current literature will refer to older literature of a particular age; but this is not the same as the likelihood that a particular item of older literature will be cited somewhere in the current literature. This rather counterintuitive fact can be illustrated by means of an imaginary example: an article may be consistently cited once or twice a year for several decades, so the chances of its being cited in a given year remain constant; whereas, because both the overall body of literature and the rate of its annual output are growing, the chances of any particular new paper referring to it decrease. It is this growth in literature, which Price had taken such care to highlight, that theorists of 'obsolescence' failed to take into account. ${ }^{42}$

In Line's view it is more accurate and useful to think of the pattern of use of a typical article as falling into two phases: an 'updating' period soon after publication, when researchers are keeping up-to-date with the latest research, and a period of normal, relatively low use thereafter. The idea of exponential decay in use is a misreading of the facts: it is probably unreasonable to assume that any library holdings will ever become wholly obsolete. ${ }^{43}$ Oppenheim and Renn have shown that, where older articles have continued to be cited often, in most cases this is because they have a material bearing on the arguments being made in

\footnotetext{
${ }^{41}$ Andrés, Measuring academic research, pp.105-110; De Bellis, Bibliometrics and citation analysis, pp.113-117.

${ }^{42}$ Price, Derek J. de Solla. Little science, big science. $2^{\text {nd }}$ ed. New York : Columbia University Press, 1965.

${ }^{43}$ Line and Sandison, 'Obsolescence', p.285-290; p.306; p.319.

See also: Moed, H. F., Leeuwen, Th. N. van, Reedijk, J. 'A New classification system to describe the ageing of scientific journals and their impact factors.' Journal of documentation [online], 1998, 54 (4), pp.387-419. <http://www.emeraldinsight.com>, [accessed 16.06.2011].
} 
the papers citing them. ${ }^{44}$ In addition to these objections, there is the familiar problem that local patterns of use may bear no clear relation to patterns of citation. So, again, bibliometric data do not seem to offer the librarian as much as might have been expected: if they are to be used at all for collections management, they must be used with local data and in accordance with local needs. Again, the possibility suggests itself of using 'half-life' or 'immediacy' data for illustrative purposes, to help with reference services and information literacy training.

\section{I2.2.3. Impact}

Garfield's 'Impact Factor' has already been mentioned (see above, I[2.1.2.). Garfield suggested early on that librarians would find it useful as a means of selecting or deselecting journals. ${ }^{45}$ The statistical advantages of this measure have already been noted, but there are problems. One of these is that citations of the journal under investigation (which make up the numerator of the I.F. equation) can be to any recent article whatever, including correspondence, obituaries and so on; whereas this figure is divided only by the number of recent research articles in the journal, i.e. new research, notes, and reviews. This gives some journals whose correspondence is often cited (e.g. The Lancet) an unfair advantage. Another problem is the choice of a two-year 'citation window': this may be appropriate for some disciplines (especially those with definite 'research fronts' and high levels of 'immediacy' in their publishing and citing practices), but not for others: this will be important in considering botanical publications. These and other complications have been discussed at length by other scholars, and it seems pointless to rehearse the arguments in detail here. Suffice it to say that the I.F. has become, in spite of its problems, a popular and well-known measure, and it (like all the other measures we have looked at) has its place alongside other statistics in helping librarians with their collections and reference work. ${ }^{46}$

Another, complementary, way of assessing the 'impact' of journals using citation analysis has been to use a modified version of the $h$-index. Here all the articles published by a journal in a given year are assembled and ranked according to the number of times cited, and $h$ is then determined by comparing rank with citation-frequency as explained above (I[2.1.2.). Its disadvantage compared to the I.F. is that where a journal only publishes comparatively

\footnotetext{
${ }^{44}$ Oppenheim, Charles, and Renn, Susan P. 'Highly cited old papers and the reasons why they continue to be cited.' Journal of the American Society for Information Science [online], 1978, 29 (5), pp.225-231. < http://web.ebscohost.com>, [accessed 12.04.2011].

${ }^{45}$ Garfield, 'Is citation frequency a valid criterion for selecting journals?'

${ }^{46}$ Andrés, Measuring academic research, pp.84-95; De Bellis, Bibliometrics and citation analysis, pp.184-241; Glänzel, Wolfgang, and Moed, Henk F. 'Journal impact measures in bibliometric research.' Scientometrics [online], 2002, 53 (2), pp.171-193. <http://www.springerlink.com>, [accessed 13.04.2011]; Moed, Citation analysis, pp.91-105.
} 
few articles in a year, the size of $h$ is limited to this number regardless of how often its articles have been cited. ${ }^{47}$

\section{I2.3. Disciplines and documents}

So far bibliometrics and its relation to librarianship have been discussed in general terms: it is also necessary to consider the specific bibliometric characteristics of documents that deal with particular subject areas, and of documents of particular types.

\subsubsection{Disciplines}

It is obvious that academic disciplines differ in their subject matter and in their working methods; they also differ in their publishing practices: as a result the character of bibliometric data drawn from publications varies from discipline to discipline, and this variation has been discussed at length in the bibliometric literature. Price's idea of the 'research front' has already been touched upon (see above, I2.2.2.): this phenomenon, where current research proceeds quickly and is focused on a clearly delimited set of problems, is characteristic of the mathematical sciences and engineering. The pattern of citation which results from this working-method is one in which only very recent work tends to be cited; older research is often wholly superseded by later developments, and only 'classics' in particular fields continue to be cited for any great time after their publication. ${ }^{48}$ Indeed if a piece of work is really fundamental, it becomes part of accepted scientific doctrine and ceases to be cited altogether: Oppenheim and Renn note that any physicist who cited the article in which Einstein unveiled his famous formula $e=m c^{2}$, would probably be mocked by his or her colleagues. ${ }^{49}$ However, as Price found, this pattern is less pronounced in or even entirely absent from other disciplines: his Index (the percentage of current references to literature not more than five years old) was usually about $60-70 \%$ for physics and biochemistry; $50-60 \%$ for medicine; $40-50 \%$ for sociology. He speculated that the humanities and what he termed the "taxonomic sciences" would have lower figures still. ${ }^{50}$

Other bibliometric studies have been carried out on the publications of particular disciplines. Notable for its size was the DISISS project (overseen by Line), in which around 100,000 references were collected from 140 journals, and a further 11,000 from 297 monographs, covering a wide range of social sciences. ${ }^{51}$ Cronin and others carried out a large scale study

\footnotetext{
${ }^{47}$ Braun, Tibor, Glänzel, Wolfgang, and Schubert, András. 'A Hirsch-type index for journals.' Scientometrics [online], 2006, 69 (1), pp.169-173. <http://www.springerlink.com>, [accessed 13.04.2011].

${ }^{48}$ Price, Little science, big science, pp.1-32; 'Citation measures', 9-15; 'Networks of scientific papers'.

49 Oppenheim and Renn, 'Highly cited old papers.'

${ }^{50}$ Price, 'Citation measures', p.15.

${ }^{51}$ Line, Structure of social science literature; Nicholas, Ritchie and Ritchie, Literature usage and interrelationships.
} 
of sociology citations (over 30,000) ${ }^{52}$ Lindholm-Romantschuk and Warner investigated citations in philosophy, sociology and economics (almost 15,000). ${ }^{53}$ They have all borne out Price's view that researchers in different fields differ in their citation habits, and that one of the more important ways in which they differ is the age of the things they cite. This has two important consequences: firstly, general bibliometric indices are likely to vary according to the discipline of the journal, scientist, etc. for which they have been calculated, regardless of the actual impact of their respective publications. For instance, because historians are less likely to cite the work of their contemporaries, an eminent historian may have a lower $h$ index than a postdoctoral physicist; or a well-known international history journal may have a lower I.F. than a relatively obscure physics journal. Secondly, the age at which library materials cease to be heavily used varies with discipline. Whether bibliometric data are used by librarians as proxies for use-data, or to complement them, they must be calculated and compared discipline-by-discipline.

\subsubsection{Types of document}

Another bibliometric variable which depends upon what research field is being investigated is the types of document that are published. Research in the mathematical sciences is published predominantly_indeed almost exclusively — in the form of articles in journals; as a result the $S C I$ was set up primarily to index journal articles, and not other forms of publication, and enormous numbers of article-citations have now been collated $;{ }^{54}$ as a further result the vast majority of citation studies have taken citations from journal articles as data. Outside the mathematical sciences things are different: not only is the range of researchinterests more diffuse, but publication is slower, notably because publication in monograph books is more important. Bibliometric studies should take this into account-according to Line, any study based solely on citations from 'core' journals is likely to be "unrepresentative". 55

It is possible to study citations from monographs, but to do so is more laborious because the citations must be collected and collated from scratch by the researcher. Even so, several

\footnotetext{
${ }^{52}$ Cronin, Blaise, Snyder, Herbert, and Atkins, Helen. 'Comparative citation rankings of authors in monographic and journal literature.' Journal of documentation [online], 1997, 53 (3), pp.263-273. <http://www.emeraldinsight.com>, [accessed 15.04.2011].

${ }^{53}$ Lindholm-Romantschuk, Ylva, and Warner, Julian. 'The Role of monographs in scholarly communication: an empirical study of philosophy, sociology and economics.' Journal of documentation [online], 1996, 52 (4), pp.389-404. <http://www.emeraldinsight.com>, [accessed 15.04.2011].

${ }^{54}$ At the time of writing Thompson Reuters claims that over forty million documents have been indexed according to their citations in the ISI Web of Science (as the SCI is now known): ISI Web of science. <http://apps.isiknowledge.com> [2011], [accessed 20.04.2011].

${ }^{55}$ Line, Maurice B. 'The Influence of the type of sources used on the results of citation analysis.' Journal of documentation [online], 1979, 35 (4), pp.365-284. <http://www.emeraldinsight.com>, [12.04.2011].
} 
studies of citations from monographs have been successfully carried out: the DISISS project and Cronin's study have already been mentioned; on a smaller scale, Cullars has studied citations taken from monographs in a number of humanities subjects. His two most recent studies are of particular interest here, because they deal with disciplines that appear to inhabit a border region between the humanities and the social sciences: linguistics and analytic philosophy. He suggests that the comparative neglect of analytic philosophy by bibliometricians may be precisely as a result of its intermediate character as a disciplinehere is a clear analogy with taxonomic botany. ${ }^{56}$ His older studies, dealing with pure humanities subjects, are perhaps of less direct interest — except in their methods, which will be returned to later in this study. Details of these studies are given in the bibliography.

Other researchers have even managed to assemble citations to monographs, apparently taking their data from ISI Web of Science. ${ }^{57}$ (The author of the present study has, experimentally, attempted to do this for some botanical monographs, without much success.) Tang's study compared citations of 750 monographs in mathematics, physics, economics, psychology, history, and religious studies: most interestingly, he was able to calculate Price's Index for each discipline based on its monographs, and he discovered that there was no statistically significant difference between the disciplines in this regard; he even discovered that the physics monographs had the longest 'cited half-life' of all the monographs. Clearly the bibliometric characteristics of monographs are different from those of journals, and deserve serious consideration in their own right by librarians.

\section{I2.3.3. Bibliometrics and taxonomic botany}

Bibliometric studies have been carried out on the literature of botany, but they are few in number and often deal with isolated problems. The following are typical: a survey of research on the marine botany of the Indian Ocean; ${ }^{58}$ a comparison of bibliometrics and peer-review methods in assessing biological (including botanical) research; ${ }^{59}$ studies of

\footnotetext{
${ }^{56}$ Cullars, John M. 'Citation characteristics of English-language monographs in philosophy.' Library and information science research [online], 1998, 20 (1), pp.41-68. <http://www.sciencedirect.com>, [accessed 02.02.2011].

Georgas, Helen, and Cullars, John. 'A citation study of the characteristics of the linguistics literature.' College and research libraries, 2005, 66 (6), pp.496-516.

${ }^{57}$ Lindholm-Romantschuk and Warner, 'Role of monographs in scholarly communication'; Tang Rong, 'Citation characteristics and intellectual acceptance of scholarly monographs.' College and research libraries [online], 2008, 69 (4), pp.356-369. 〈http://crl.acrl.org>, [accessed 11.04.2011]. ${ }^{58}$ Erftemeijer, P. L. A., Semesi, A. K., Ochieng, C. A. 'Challenges for marine botanical research in East Africa: results of a bibliometric survey.' [Abstract only.] South African journal of botany [online], 2001, 67 (3), pp.411-419. <http://ajol.info/index.php/sajb/article/view/20456/0>, [accessed 01.02.2011].

${ }^{59}$ Lovegrove, Barry G., and Johnson, Steven D. 'Assessment of research performance in biology: how well do peer-review and bibliometry correlate?' [Abstract only.] BioScience [online], 2008, 58 (2), pp.160-164. <http://www.bioone.org>, [accessed 02.02.2011].
} 
citations in issues of botanical journals in particular sub-disciplines; $;{ }^{60}$ a survey of works about pomegranates. ${ }^{61}$ These studies (and others like them) are disparate and so not easily comparable; they do not, taken together, provide a coherent picture of the literature of botany as a whole, or of taxonomic botany in particular-indeed they are not intended to.

Some bibliometricians have mentioned botany more or less in passing when discussing the comparative bibliometric characteristics of different disciplines. Price's remark about "taxonomic sciences" has already been noted (above, I[2.3.1.); he explicitly identified taxonomic botany as a "strongly classic" discipline, placing it closer to social sciences and humanities than to the physical sciences, at least in terms of its citation-habits; ${ }^{62}$ Line and Sandison made a similar assertion; ${ }^{63}$ but none of these scholars systematically investigated botanical literature with this in mind.

The problem of botanical journals in the SCI exercised Garfield intermittently for some years, and he published several short papers on the subject. ${ }^{64}$ Garfield noticed that individual botanists were not among the 250 most frequently cited scientists whose articles appeared in the SCI; that the majority of the articles most often cited in botany journals were not themselves published in botany journals; that (by contrast) non-botanical articles very rarely cited botanical ones; that botanical journals had relatively low Impact Factors. He gave various explanations: botanists tended to describe themselves as biochemists, molecular biologists, and so on, which skewed data away from botany; botany was a derivative science which drew upon more basic sciences than itself (such as chemistry), but was not drawn upon by others; botany was deeply divided into sub-disciplines and -fields which did not cite each other's work very often. These are important conclusions, but may to some extent have been vitiated by problems with the SCI itself.

Two particular studies have set out to deal with the overall characteristics of botanical literature. The first, by Nordstrom, analysed references in articles the 1985 numbers of The Canadian Journal of Botany (which dealt with taxonomy and other purely scientific topics) and The Canadian Journal of Plant Science (horticulture, agriculture, etc.), and found little

\footnotetext{
${ }^{60}$ Biswas, Bidhan Ch., Roy, Amit, and Sen, B. K. 'Economic Botany: a bibliometric study.' Malaysian journal of library and information science [online], 2007, 12 (1), pp.22-33. <http://majlis.fsktm.um.edu.my/document.aspx?FileName=513.pdf >, [accessed 01.02.2011]. MacRoberts, M. H., and MacRoberts, B.R. 'Citation content analysis of a botany journal.' Journal of the American Society for Information Science [online], 1997, 48 (3), pp.274-275. <http://web.ebscohost.com>, [accessed 01.02.2011].

${ }^{61}$ Al-Qallaf, Charlene L. 'A bibliometric analysis of the Punica grantum [sic] L. literature.' Malaysian journal of library and information science [online], 2009, 14 (1), pp.83-103. <http://majlis.fsktm.um.edu.my/document.aspx?FileName=731.pdf>, [accessed 01.02.2011].

${ }^{62}$ Price, 'Networks of scientific papers', p.514.

${ }^{63}$ Line and Sandison, 'Obsolescence', p.317.

${ }^{64}$ These have been reproduced in his Essays of an Information Scientist-for details see bibliography.
} 
apparent difference between the two. ${ }^{65}$ The second study, by Delendick, analysed references in the 1986 numbers of three taxonomic journals, Brittonia, Systematic Botany, and Taxon. ${ }^{66}$ He took into account references to monographs as well as to other journals. He criticized Garfield's assessment of botanical literature on the grounds that the SCI did not (in 1990) index articles from a number of the most important taxonomical journals, but tended to concentrate on biochemical and physiological botany-this explained what Delendick had already gathered anecdotally, that taxonomists preferred to use Biological Abstracts rather than the $S C I .{ }^{67}$ However, despite criticizing Garfield, Delendick arrived at substantially similar conclusions: that taxonomists were subdivided into groups of specialists; and that their research was more than usually derivative in character for a natural science.

From the foregoing review it clearly emerges that there is work to be done on the bibliometrics of taxonomic botany: it is a discipline whose documentation has particular bibliometric characteristics that set it apart from the documentation of other scientific disciplines. It is also clear that bibliometric data have a place alongside other kinds of data in helping collections management and subject specialist librarians to do their jobs. These two considerations underlie the aims of this study.

\footnotetext{
${ }^{65}$ Nordstrom, L. O. 'Applied versus basic science in the literature of plant biology: a bibliometric perspective.' Scientometrics [online], 1987, 12 (5-6), pp.381-393. <http://www.springerlink.com>, [accessed 14.04.2011].

${ }^{66}$ Delendick, Thomas J. 'Citation analysis of the literature of systematic botany: a preliminary survey.' Journal of the American Society for Information Science [online], 1990, 41 (7), pp.535-543. <http://web.ebscohost.com>, [accessed 31.01.2011].

${ }^{67}$ BIOSIS Biological Abstracts has since been acquired by Thompson Reuters, and is available on-line alongside ISI Web of Science.
} 


\section{§3. Aims and objectives}

This study has sought to clarify and quantify what is already known by botanists: that published documents in taxonomic botany may remain useful for a long time after publication; and that monographs are considerably more important to botanists than they are to scientists in other disciplines.

The main objectives were:

1) to identify the 'core' journals in taxonomic botany

2) to identify the most important publishers of monographs in taxonomic botany

3) to determine the importance of monographs compared to that of journals

4) to determine the age of current documentation, and whether and to what extent its use changes over time.

This may be of some interest to people working in taxonomic botany or in bibliometrics generally. More specifically the findings should be of use to librarians who may not be very familiar with botany, but who are responsible for managing collections which include botany materials, or for dealing with reference queries on the subject in, say, a general university library. The results of this study should help collections management decisions to be made by providing the librarian with evidence which supplements other, local, evidence, such as the results of user-profiling or user surveys, and of course local circulation statistics. The attention which this study devotes to monographs may also be of broader interest to librarians who work in collections management in fields other than botany, where monographs are still relatively important, such as the humanities and the social sciences. 


\section{§4. Method}

\section{II4.1. Citations}

This research has been carried out by collecting and analysing citations taken from botanical monograph books. This method is unusual and requires the citations to be collected manually: the ISI Web of Science deals predominantly with journal-citations, and there is no equivalent citation index for books. However, taking citations from books has the advantage of enabling a better assessment to be made of the precise significance of books as opposed to journals within the field (which is one of the objectives of this study). It was intended that this citation-data should be collected in such a way as to make it comparable with data from $I S I$, to further test this significance (see below, II4.4.1.).

In any citation-study it is necessary to consider what is to be done with so-called 'internal citations.' These occur where the author of a document refers to another document in the body of the text or in a footnote, usually for explanatory purposes, but does not formally cite the document in a bibliography. Such internal citations usually refer to acknowledged classics or basic texts, and are quite common in the humanities: someone writing about Jacobean literature, for instance, may cite poems of Donne or passages from the King James Bible without including them in a list of bibliographical references. Taxonomic botanists also make internal citations, but in a very particular way: every time a species of plant is formally named, an internal reference occurs. The full scientific name of the horseradish plant is Armoracia rusticana G.Gaertn., B.Mey. \& Scherb. The abbreviations which follow the Latin binominal indicate that three botanists made the original identification: Gottfried Gaertner, Bernhard Meyer, and Johannes Scherbius; and the International Plant Names Index tells us that they published their findings in their Oekonomisch-technische Flora der 
Wetterau (Frankfurt am Main : P. H. Guilhauman, 1799-1802). ${ }^{68}$ In cases where botanists are trying to resolve problems of nomenclature, references of this kind (and other more expanded versions) are important—but in many cases they are not. The case of horseradish shows how much unnecessary detail could be added to botanical publications if citations of this kind were always given in full. Delendick decided to include internal citations in his study where it was possible to identify them. ${ }^{69}$ His study was based solely on journal articles, where it would have been comparatively easy to spot and to trace all such references: but to do so with a large number of monographs would have been excessively time-consuming and it has not been attempted here. This is a shame, because it would have helped to determine precisely which are the most important of the oldest materials used by taxonomic botanists.

\section{I44.2. Sampling}

The sampling process of most citation-studies has two stages: firstly a sample is taken of the existing documentation, from this a sample of citations is taken-these are the data to be analysed. ${ }^{70}$ In an ideal world, the bibliometrician would have a complete bibliography of the field to work from as a sampling frame: but of course it is the impossibility of such a bibliography that makes a bibliometric approach necessary in the first place. ${ }^{71}$ In this study, the holdings of relevant monographs in the Library of the Royal Botanic Gardens, Kew, have been taken as the sampling frame. This Library is widely acknowledged to be one of the most important botanical libraries in the world, and its holdings have been designated a national reference collection in the National Heritage Act (1983). ${ }^{72}$ It was therefore thought to provide as good a population of botanical books to work from as could practically be obtained: "in practice, the population defined by access may well be regarded as the only meaningful population anyway." 73

Broadly speaking, the method and scale of sampling has followed the example of Cullars (see above, I[2.3.2.). His studies of citations from monographs appear to have won scholarly acceptance: ISI Web of Science and Google Scholar both indicate that for his seven citationstudies $h=7$ (i.e. it is as high as it can be). ${ }^{74}$ It was intended that at least fifty monographs

\footnotetext{
${ }^{68}$ International plant names index [online]. <http://www.ipni.org/index.html> [2011], [accessed 01.02.2011].

${ }^{69}$ Delendick. 'Citation analysis of the literature of systematic botany,' pp.538-539.

${ }^{70}$ Of course, in journal citation-studies, ISI has already done most of this work.

${ }^{71}$ The enormous bulk of scientific documentation was already a problem in the 1930s, and was what called bibliometrics into existence: $c f$. Bradford, Documentation, pp.149-159.

${ }^{72}$ National Heritage Act (1983) [online]. <http://www.legislation.gov.uk/ukpga/1983/47/contents> [2011], [accessed 30.01.2011].

The Library has also appeared in a better-known publication: Griffiths, Mark. 'Kew's Library is an open book.' Country life, 2011, 205 (9), p.121.

${ }_{73}^{73}$ Nicholas and Ritchie, Literature and bibliometrics, p.161.

${ }^{74}$ ISI Web of science, <http://apps.isiknowledge.com> [2011], [accessed 20.04.2011]; Google scholar. $<$ http://scholar.google.co.uk> [2011], [accessed 20.04.2011].
} 
would be used as source-documents. These were selected in a semi-structured way using the OPAC of the Library at Kew: thirty floras were selected, and thirty revisions and other monographs, in order to give equal representation to each type. It may be thought that this decision was arbitrary and to some extent begged the question. However, it was stated at the outset that floras and revisions are of equal interest to the present study (see above, I1.2.); and it was not part of this study to determine their relative importance, so intentionally to have given them equal representation in sampling has not, in fact, prejudged any results. The reason for selecting sixty monographs in total was that it was thought unlikely to be possible to obtain references from all of them. The monographs were selected at random from the OPAC search results; from each monograph ten citations were then selected at random, giving approximately 500 in total. At both stages random numbers were obtained using a website intended for this purpose. ${ }^{75}$

When dealing with journal articles, bibliometricians tend to study citations made in a single year, on the grounds that journal articles are published relatively promptly according to some sort of annual pattern; by contrast, it is perhaps arguable that the "slow, irregular and bulky transmission of knowledge" effected by book publishing ought not to be treated in the same way. Nicholas and Ritchie do in fact argue this, and claim to regard one year's monographic publication within a field to be unrepresentative of the literature of that field. Nevertheless their own study, carried out as part of DISISS, dealt with monographs published only in $1971 .^{76}$ Some monograph citation-studies by Cullars also deal with citations from monographs published in a single year, so it was decided to follow this practice here. ${ }^{77}$ Only monographs published in 2009 were selected. The advantage of this will be made clear shortly.

\section{I4.3. Data collected}

Data were recorded both for source documents and for documents cited. Firstly, basic bibliographical data were collected, i.e. author, title, journal title (where applicable, and with number, issue and page numbers), place of publication (including country), publisher, and date. The type of document cited was noted (book, article, conference proceedings, thesis, or grey literature). The language of the citing and cited documents was also recorded. In

\footnotetext{
${ }^{75}$ Random.org [2011], <http://www.random.org> [accessed 13.06.2011].

${ }^{76}$ Nicholas and Ritchie, Literature and bibliometrics, p.35; 40.

Cf. Nicholas, Ritchie and Ritchie, Literature usage, p.8.

${ }^{77}$ Cullars, John M. 'Citation characteristics of monographs in the fine arts.' Library quarterly, 1992 , 62 (3), pp.325-342.

- 'Citation characteristics of French and German literary monographs.' Library quarterly, 1989, 59 (4), pp.305-325.

-. 'Citation characteristics of English-language monographs in philosophy.' Library and information science research [online], 1998, 20 (1), pp.41-68. <http://www.sciencedirect.com>, [accessed 02.02.2011].
} 
dealing with works by several authors, the first three authors only were recorded: this was intended to be a compromise between the misleading data which would have resulted from recording only the first author, and the excessive data which would have resulted from recording all of them. ${ }^{78}$

\section{I4.4. Analysis}

Once citation-data were gathered, they were analysed (using SPSS/PASW software) to provide information suitable for answering the questions set out in $\S 3$ above.

\subsection{1. 'Core' journals}

Citations to journals were tabulated by frequency and the journals ranked. This in itself gave a good indication of which journals were more or less important-it was taken further by determining whether cited articles were distributed in a Bradfordian pattern among the journals.

It was also possible to calculate a sort of monograph Impact Factor of journals using these citations combined with data from ISI: journals were ranked again on this basis. The point of this was to see whether the impact of journal articles on monographs differed from their impact on other journal articles. It is because Impact Factors can only be calculated using one year's citing documents, that the sample of citing monographs for the present study was taken from only one year (see above, 944.2.). Since monograph publishing is comparatively slow, it makes no sense to calculate a monograph I.F. of a journal using a two-year citation window, as is done when calculating an ordinary I.F. Instead, a ten year window was used. Garfield himself has remarked on the possibility of calculating impact factors using different citation windows: he had in mind allowing for differences between disciplines - in the present study it was intended to allow for differences between formats. ${ }^{79}$ The monographcitation I.F. was therefore calculated as follows:

$$
\text { monograph I. F. of journal } x=\frac{\begin{array}{c}
\text { no. of citations in monographs published in } 2009 \\
\text { of articles published in journal } x \text { in } 1999-2008
\end{array}}{\text { no. of research articles published in journal } x \text { in 1999-2008 }}
$$

The year 2009 was selected because, at the time of writing, ISI had only produced I.F.s for 2009. It was therefore be possible to compare this monograph I.F. ranking with the true I.F. ranking drawn from ISI figures alone.

\subsubsection{Major publishers}

${ }^{78}$ Persson, Olle. 'All author citations versus first author citations.' Scientometrics [online], 2001, 50 (2), pp.339-344. <http://www.springerlink.com>, [accessed 13.06.2011].

${ }^{79}$ Garfield, Eugene. 'Dispelling some common myths about journal citation impacts.' Scientist [online], 1997, 11 (3). <http://www.the-scientist.com>, [accessed 06.06.2011].

See also: Andrés, Measuring academic research, p.125.

ISI Web of Science now provides five-year I.F.s alongside conventional I.F.s. 
Publishers were tabulated and ranked according to the number of citations made of their publications.

\section{II4.4.3. Botanical monographs and botanical journals compared}

It was possible to tabulate the frequency with which different types of document (including journal articles and monograph books) are cited, and to compare them.

Calculating monograph I.F.s of journals and comparing them to their true I.F.s has already been mentioned (above, I44.4.1.). This comparison was intended to illustrate the relative impact of journal articles and their journals, i.e. of the documents cited. However, it was also intended to look at the monograph I.F.s and true I.F.s in terms of the citing documents. This may have shown whether or not research botanists made citations differently in journal articles from how they made citations in monographs.

\subsubsection{Current documentation and changes in its use over time}

Cited documents were distributed by age - this was represented graphically. The median age of citations (i.e. the 'citing half-life' of the monographs) was calculated; but it was more meaningful to look at the distribution in terms of the 'updating' and 'normal' use of the documents (following Line - see above, I[2.2.2.). It is unfortunate that a study of the 'cited half-life' of monographs (or what Line would have called a 'diachronous study') cannot be carried out — this would have required a citation index of botany books.

Two further age-distributions were produced, one of cited books and one of cited journals, in order to supplement the analysis outlined in $\mathbb{I} 4$.4.3. 


\section{§5. Results}

It was possible to obtain only 454 citations from 47 monographs. This was fewer than was intended, but it should be noted that Cullars, whose sampling methods the present study imitates, has relied on samples that varied in size from as many as 581 citations to as few as $3900^{80}$

\section{1. 'Core' journals}

In the event, calculating a ten-year Impact Factor for journals using monograph-citations has not produced satisfactory results. Tables 1 and 2 show these results. There is clearly no correlation between the ranking obtained from the monograph citations and the ranking of the same journals according to the conventional I.F. as calculated by ISI. Many of the journals listed are in subject areas other than what ISI calls 'Plant sciences': the subject areas that these belong to are indicated in the tables. If these non-botanical journals are taken out the rankings, the situation is not improved, and still no clear correlation can be obtained.

\footnotetext{
${ }^{80}$ Cullars, John M. 'Citation characteristics of French and German fine arts monographs.' Library quarterly, 1996, 66 (2), pp.138-160 (390 citations). 2. 'Citation characteristics of monographs in the fine arts.' Library quarterly, 1992, 62 (3), pp.325-342 (581 citations).
} 
Table 1: 10-year monograph Impact Factors

\begin{tabular}{|c|c|c|c|c|}
\hline Rank & Title & $\begin{array}{l}\text { Monograph- } \\
\text { citations } \\
(1999-2008)\end{array}$ & $\begin{array}{l}\text { Research } \\
\text { articles } \\
(1999-2008)\end{array}$ & $\begin{array}{l}\text { 10-year } \\
\text { monograph } \\
\text { I.F. (2009) }\end{array}$ \\
\hline 1 & Adansonia & 1 & 72 & 0.013888889 \\
\hline 2 & $\begin{array}{l}\text { Latin American Journal of Pharmacy [under } \\
\text { 'Pharmacology and pharmacy'] }\end{array}$ & 2 & 288 & 0.006944444 \\
\hline 3 & Systematic Botany & 2 & 652 & 0.003067485 \\
\hline 4 & $\begin{array}{l}\text { Proceedings of the Biological Society of } \\
\text { Washington [under 'Biology'] }\end{array}$ & 2 & 669 & 0.002989537 \\
\hline 5 & Novon & 3 & 1035 & 0.002898551 \\
\hline 6 & Journal of Ecology & 3 & 1039 & 0.002887392 \\
\hline 7 & Botanical Journal of the Linnean Society & 3 & 1117 & 0.002685765 \\
\hline 8 & Brittonia & 1 & 427 & 0.00234192 \\
\hline 9 & Journal of Bryology & 1 & 482 & 0.002074689 \\
\hline 10 & Bryologist & 1 & 694 & 0.001440922 \\
\hline 11 & Nova Hedwigia & 1 & 763 & 0.001310616 \\
\hline 12 & Taxon & 1 & 992 & 0.001008065 \\
\hline 13 & American Journal of Botany & 2 & 1985 & 0.001007557 \\
\hline 14 & Plant systematics and evolution & 1 & 1039 & 0.000962464 \\
\hline 15 & International Journal of Plant Sciences & 1 & 1101 & 0.000908265 \\
\hline 16 & $\begin{array}{l}\text { Philosophical Transactions of the Royal } \\
\text { Society of London [under 'Biology'] }\end{array}$ & 1 & 1145 & 0.000873362 \\
\hline 17 & Canadian Journal of Plant Science & 1 & 1691 & 0.000591366 \\
\hline 18 & $\begin{array}{l}\text { Molecular Biology and Evolution [under } \\
\text { 'Biochemistry and molecular biology'] }\end{array}$ & 1 & 2551 & 0.000392003 \\
\hline 19 & New Phytologist & 1 & 2845 & 0.000351494 \\
\hline 20 & Oecologia [under 'Ecology'] & 1 & 2984 & 0.000335121 \\
\hline 21 & $\begin{array}{l}\text { Molecular Ecology [under 'Biochemistry } \\
\text { and molecular biology'] }\end{array}$ & 1 & 3362 & 0.000297442 \\
\hline 22 & Nature [search by title] & 1 & 27529 & $3.63253 \mathrm{E}-05$ \\
\hline
\end{tabular}


Table 2: Conventional Impact Factors

\begin{tabular}{|r|l|r|}
\hline Rank & Title & I.F. (2009)* \\
\hline 1 & Nature [search by title] & 34.48 \\
2 & Molecular Biology and Evolution [under 'Biochemistry and & 9.872 \\
& molecular biology'] & \\
3 & New Phytologist & 6.033 \\
4 & Molecular Ecology [under 'Biochemistry and molecular biology'] & 5.96 \\
5 & Philosophical Transactions of the Royal Society of London [under & 5.117 \\
& 'Biology'] & \\
6 & Journal of Ecology & 4.69 \\
7 & Oecologia [under 'Ecology'] & 3.129 \\
8 & Taxon & 2.747 \\
9 & American Journal of Botany & 2.604 \\
10 & International Journal of Plant Sciences & 2.358 \\
11 & Systematic Botany & 1.697 \\
12 & Plant systematics and evolution & 1.41 \\
13 & Botanical Journal of the Linnean Society & 0.984 \\
14 & Bryologist & 0.842 \\
15 & Nova Hedwigia & 0.763 \\
16 & Proceedings of the Biological Society of Washington [under & 0.643 \\
& 'Biology'] & \\
17 & Canadian Journal of Plant Science & 0.609 \\
18 & Journal of Bryology & 0.576 \\
19 & Brittonia & 0.384 \\
20 & Adansonia & 0.359 \\
21 & Latin American Journal of Pharmacy [under 'Pharmacology and & 0.309 \\
& pharmacy'] & \\
\hline
\end{tabular}

* ISI Web of Science. <http://apps.isiknowledge.com> [2011], [accessed 20.07.2011]. 
However, it has been possible to obtain a Bradford-type distribution of the frequency of citation of journals, regardless of date. Traditionally, Bradford distributions are done by ranking journals in terms of the number of subject-relevant articles that they contain; here they are ranked by the number of citations that their articles have received instead. This innovation was first made by Garfield, which is not surprising, since the assumption that citations can be treated as surrogates for subject-descriptors lies at the root of his citationindexes (see above, I[2.2.1., and esp. n.32). This, of course, is related to the assumption that citations can be treated as an indicator of the quality and importance of a piece of researcha view explicitly endorsed by the present study (see above, I2.1.3.).

Table 3: Journal productivity of cited articles

\begin{tabular}{|r|l|l|l|l|l|}
\hline $\begin{array}{l}\text { Journal } \\
\text { rank }\end{array}$ & $\begin{array}{l}\text { No. of } \\
\text { journals }\end{array}$ & $\begin{array}{l}\text { No. of } \\
\text { articles } \\
\text { cited }\end{array}$ & $\begin{array}{l}\text { Cumulative } \\
\text { no. of } \\
\text { journals }\end{array}$ & $\begin{array}{l}\text { Cumulative } \\
\text { no. of } \\
\text { articles cited }\end{array}$ & $\begin{array}{l}\text { Cumulative } \\
\text { per cent. of } \\
\text { articles cited }\end{array}$ \\
\hline 1 & 1 & 10 & 1 & 10 & 4.5 \\
2 & 1 & 9 & 2 & 19 & 8.6 \\
3 & 1 & 8 & 3 & 27 & 12.2 \\
4 & 1 & 7 & 4 & 34 & 15.4 \\
5 & 1 & 6 & 5 & 40 & 18.1 \\
6 & 2 & 5 & 7 & 50 & 22.6 \\
7 & 4 & 4 & 11 & 66 & 29.9 \\
8 & 13 & 3 & 24 & 105 & 47.5 \\
9 & 12 & 2 & 36 & 129 & 58.4 \\
10 & 92 & 1 & 128 & 221 & 100.0 \\
\hline
\end{tabular}

The distribution may be divided into three 'zones' of a Bradfordian type - this seems a reasonable number of zones considering the relatively small number of journals cited. Each zone in the distribution produces the same number of cited articles, but the number of journals in each zone increases as the number of cited articles each has produced decreases (see above, I[2.1.1.). Of these 128 journals, the eleven most highly cited journals (ranks 1-7) account for almost a third of all citations, and the 24 most highly-cited journals (ranks 1-8) account for nearly half. The boundary of the 'core' group of journals is therefore observed to fall somewhere in rank 8 (i.e. somewhere between the $11^{\text {th }}$ and the $24^{\text {th }}$ most highly-cited journal). There is an established mathematical formula which shows whether citationdistributions are of a Bradfordian kind, and can show more precisely which journals fall into what parts of the distribution. ${ }^{81}$ The numbers of journals in each zone are related to each other in the ratio:

$1: n: n^{2}: n^{3} \ldots$ and so on, for any number of zones.

${ }^{81}$ The remainder of this discussion follows Andrés, Measuring academic research, pp.34-37. 
$n$ can be calculated as follows:

$n=\left(e^{\gamma} \times Y_{m}\right)^{1 / p}$

where $e=2.7182$ (Euler's Number)

$\gamma=0.5772$ (the Euler-Mascheroni Constant)

$Y_{m}=$ maximum journal output (i.e. no. of articles cited from each journal in rank 1)

$=10$

$p=$ number of zones

$=3$

so here $n=2.6115$.

To determine which journals belong to the first zone, or core, of most highly-cited journals, the following formula is used:

$$
r_{0}=\frac{T(n-1)}{\left(n^{p}-1\right)}
$$

where $r_{0}=$ number of journals in the core group

$T=$ total number of cited journals

so here $r_{0}=\frac{128(2.6115-1)}{\left(2.6115^{3}-1\right)}$

$=12.2706$

$\approx 12$.

So the first twelve journals are the core journals here. How many journals fall into the second and third zones can be determined by applying the ratio $1: n: n^{2}$ :

$$
\begin{aligned}
& r_{1}=n r_{0} \\
& =2.6115 \times 12.2706 \\
& =32.0447 \\
& \approx 32 \\
\text { and } \quad & r_{2}=n^{2} r_{0} \\
& =2.6115^{2} \times 12.2706 \\
& =83.6847 \\
& \approx 84 .
\end{aligned}
$$

That the figures for each of these zones add up to 128 , and that they correspond to the per cent. distribution of articles as observed (see table 3), show that the present figures really do fall into a Bradford curve. The 'core' journals are therefore the first twelve, and are the following:

Kew Bulletin (10 citations)

Bulletin de la Société Botanique de France (9) 
Botanical Journal of the Linnean Society (8)

American Journal of Botany (7)

Systematic Botany (6)

Canadian Journal of Plant Science (5)

Watsonia (5)

New Phytologist (4)

Novosti sistematiki nizshikh rastenii (4)

Taxon (4)

Ukrainskii botanichnii zhurnal (4)

Botaniska notiser (3).

Most of these are well-known to botanists and are regarded as authoritative. (The presence of Ukrainskii botanichnii zhurnal and Novosti sistematiki nizshikh rastenii in this core group is an anomaly - see below, II6.1.) Seven of these core journals are indexed by ISI Web of Science:

New Phytologist (Impact Factor for $2009=6.033$ )

Taxon (2.747)

American Journal of Botany (2.604)

Systematic Botany (1.697)

Botanical Journal of the Linnean Society (0.984)

Botaniska notiser (0.868)

Canadian Journal of Plant Science (0.609).

According to $I S I$, the aggregated I.F. of all journals publishing in the discipline 'Plant life' in 2009 was 2.458 (this is effectively the mean I.F. of all journals in the discipline); the median I.F. of these journals in 2009 was 1.218. Four of the 'core' journals identified here have I.F.s exceeding the median I.F. for the discipline; three have I.F.s exceeding the mean. Of course, Impact Factor measures how recent citations are, as well as how frequent, so it is perhaps not surprising that so few of the 'core' journals of this study have higher-thanaverage I.F.s. 


\section{II5.2. Major publishers}

Table 4 shows all the publishers of monographs whose output was cited more than once:

Table 4: Publishers of monographs cited

\begin{tabular}{|c|c|c|c|c|}
\hline No. & Publisher & Citations & Per cent. & $\begin{array}{l}\text { Cumulative } \\
\text { per cent. }\end{array}$ \\
\hline 1 & Cambridge University Press & 8 & 3.6 & 9.9 \\
\hline 2 & Timber Press & 7 & 3.1 & 13.0 \\
\hline 3 & [author] & 4 & 1.8 & 14.8 \\
\hline 4 & Botanical Survey of India & 4 & 1.8 & 16.6 \\
\hline 5 & Royal Botanic Gardens, Kew & 4 & 1.8 & 18.4 \\
\hline 6 & Springer & 4 & 1.8 & 20.2 \\
\hline 7 & Reeve & 3 & 1.3 & 21.5 \\
\hline 8 & Science Press & 3 & 1.3 & 22.9 \\
\hline 9 & Succulent Plant Trust & 3 & 1.3 & 24.2 \\
\hline 10 & Backhuys & 2 & 0.9 & 25.1 \\
\hline 11 & Barrabés Editorial & 2 & 0.9 & 26.0 \\
\hline 12 & Batsford & 2 & 0.9 & 26.9 \\
\hline 13 & $\begin{array}{l}\text { Botanical Research Institute of Texas and } \\
\text { Austin College }\end{array}$ & 2 & 0.9 & 27.8 \\
\hline 14 & BSBI & 2 & 0.9 & 28.7 \\
\hline 15 & C. G. Sulpke & 2 & 0.9 & 29.6 \\
\hline 16 & $\begin{array}{l}\text { Crown Agents for Oversea Governments } \\
\text { and Administration }\end{array}$ & 2 & 0.9 & 30.5 \\
\hline 17 & Edinburgh University Press & 2 & 0.9 & 31.4 \\
\hline 18 & Éditions Biotope & 2 & 0.9 & 32.3 \\
\hline 19 & Efstathiadis & 2 & 0.9 & 33.2 \\
\hline 20 & Government Press (British India) & 2 & 0.9 & 34.1 \\
\hline 21 & L. Salvius & 2 & 0.9 & 35.0 \\
\hline 22 & Mediterraneo Editions & 2 & 0.9 & 35.9 \\
\hline 23 & National Botanic Gardens of South Africa & 2 & 0.9 & 36.8 \\
\hline 24 & New York Botanical Garden & 2 & 0.9 & 37.7 \\
\hline 25 & Oxford University Press & 2 & 0.9 & 38.6 \\
\hline 26 & Sinauer & 2 & 0.9 & 39.5 \\
\hline 27 & University of Texas Press & 2 & 0.9 & 40.4 \\
\hline 28 & University of Wisconsin Press & 2 & 0.9 & 41.3 \\
\hline
\end{tabular}

The total number of monographs cited is 224 (see below, I[5.3.); the total number of monograph publishers is 160 . The 28 publishers above $-17.5 \%$ of the total—account for $41.3 \%$ of the cited monographs. 
915.3. Botanical monographs and botanical journals compared

Table 5 shows the relative frequencies of citation of different types of document.

Table 5: Cited document type

\begin{tabular}{|l|r|r|}
\hline & Citations & Percent \\
\hline Monograph books & 224 & 49.3 \\
Journal articles & 221 & 48.6 \\
Grey literature & 4 & 0.9 \\
Theses & 4 & 0.9 \\
Conference proceedings & 1 & 0.2 \\
Total & $\mathbf{4 5 4}$ & $\mathbf{1 0 0 . 0}$ \\
\hline
\end{tabular}

It is interesting that citations of monographs and of journal articles are so evenly balanced. The relative ages of different types of cited document will be shown in the next section.

Because there is no clear relationship between the conventional I.F.s (where the citing documents are journal articles) and the ten-year monograph I.F.s (where the citing documents are monographs), it is not possible to compare the citing habits of botanists when they publish their research in these two different kinds of document (see above, II4.4.3. and I5.1.). 


\subsection{Current documentation and changes in its use over time}

Figure 1 shows the distribution of documents by age, in intervals of $12^{1 / 2}$ years.

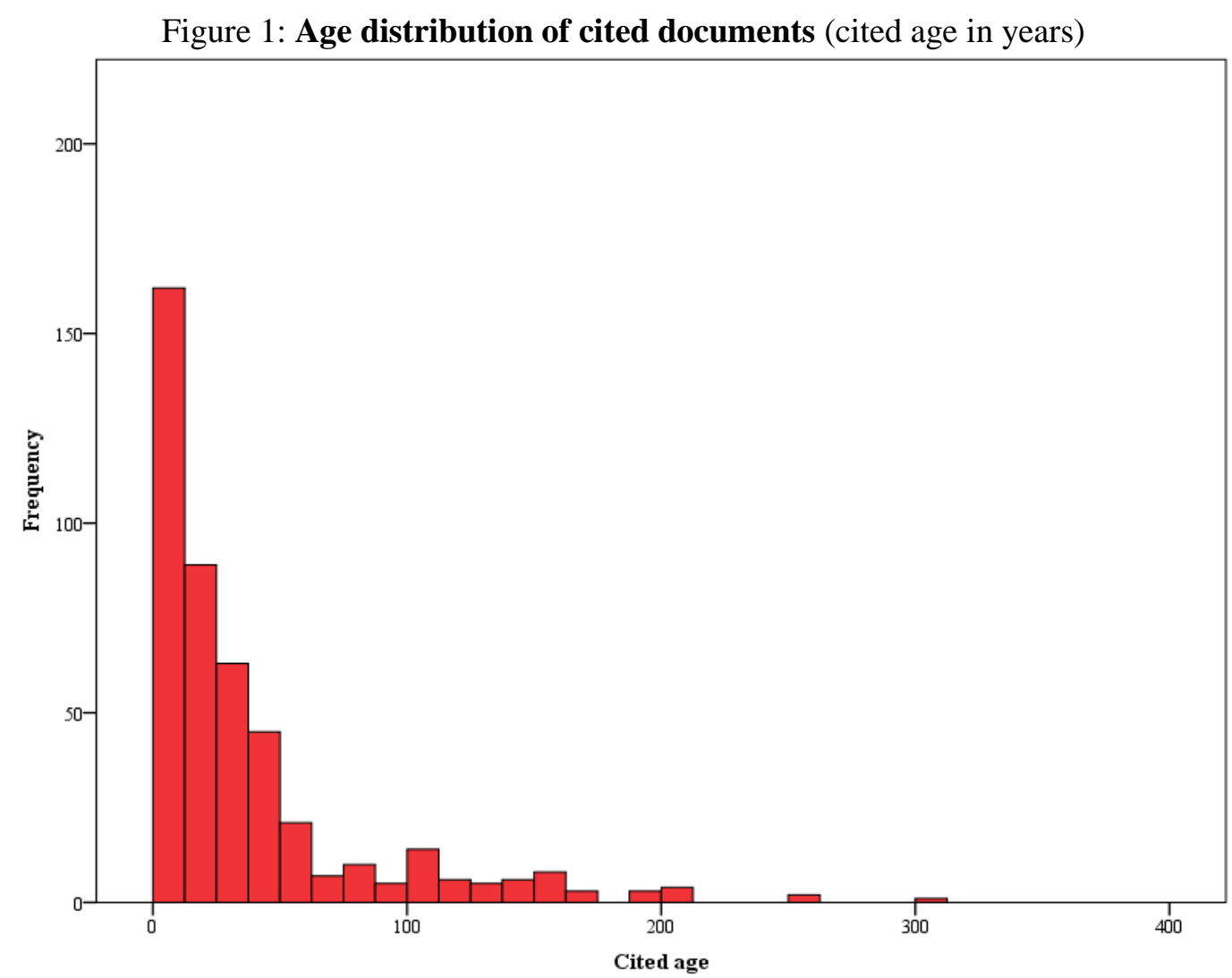

The general shape of the distribution is what would be expected for the documentation of any discipline: that the most recent documents are the most highly-cited, and that there is a fairly steady falling off in citations. The citation-frequency appears to be in inverse proportion to the age of the documents. 
The nature of this inverse relation is perhaps seen more precisely when the results are tabulated (see below, tables 6-9). It is notable that monographs refer most of all to documents between six and ten years old, and not to the very newest material - this is probably just because of the slowness of book publishing. It probably more significant that a majority of documents cited are over twenty years old.

Table 6: Age of all documents cited

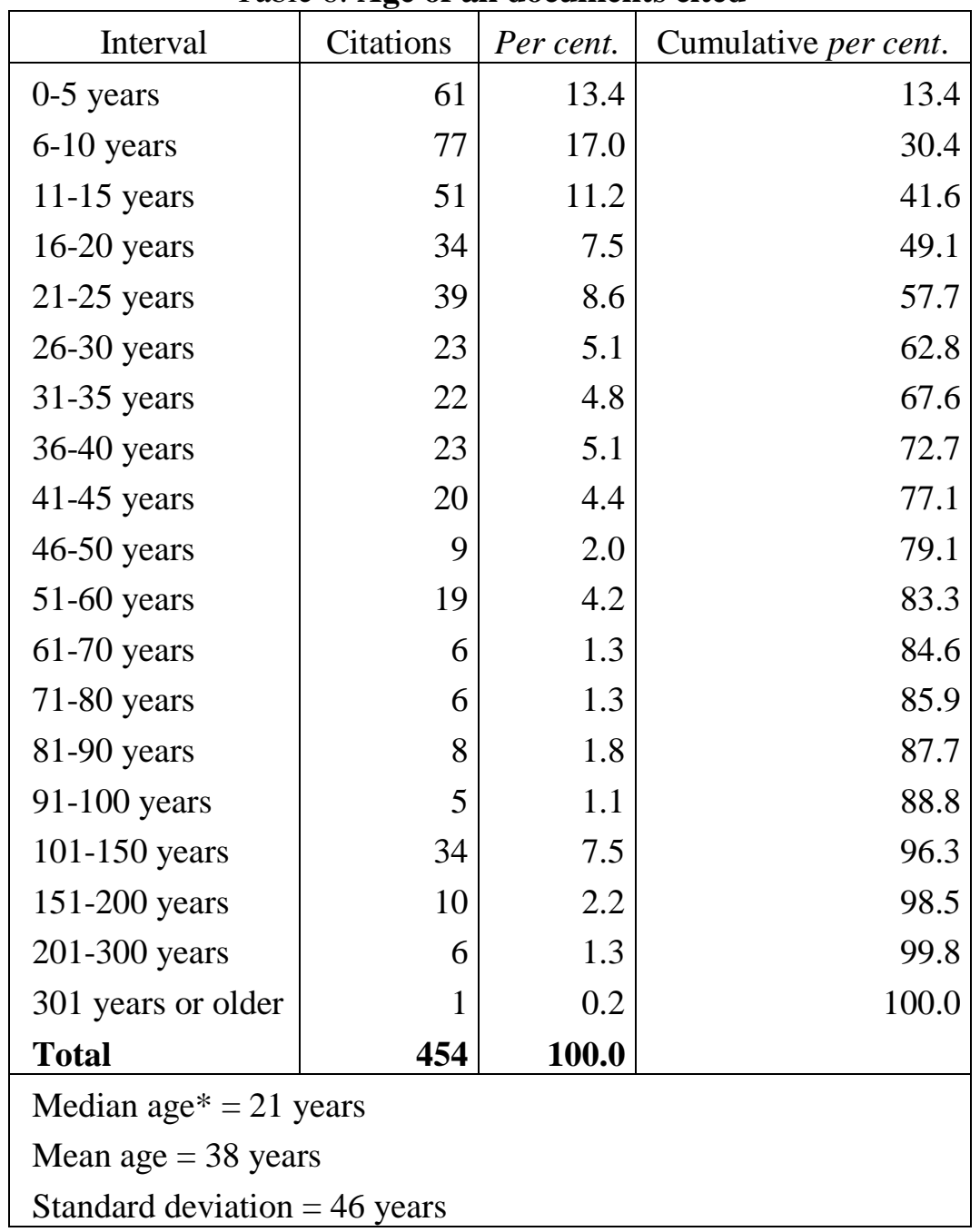

* or 'citing half-life' of source-monographs

The difference between the mean and the median age of the documents cited gives an idea of how 'skewed' away the present data are from a normal distribution. Price's Index for the citing monographs-i.e. the per cent. of their references to documents not greater than 5 years old - is $13.4 \%$ (see above, $\Phi[2.2 .2$.). In his own brief study, Price himself found that journals in different disciplines had the following Price's Indices:

physics, biochemistry: 60-70\%

medicine: $50-60 \%$ 
social sciences: $40-50 \%$

some humanities: $c .10 \%$

academic research as a whole: c. $32 \% .^{82}$

He remarked that "the taxonomic sciences" would probably rank somewhere near the humanities. The present data would prove him right, but for the fact that they are drawn from monographs, whereas Price was dealing with citations in journal articles. Price had in fact found that botany journals had Price's Indices ranging from $21 \%$ to $40 \%$. Given the comparative slowness of book publishing, it is not surprising that the present figure is somewhat lower. ${ }^{83}$

Table 7 gives the ages of cited journal articles only:

Table 7: Age of journal articles cited

\begin{tabular}{|l|r|r|r|}
\hline \multicolumn{1}{|c|}{ Interval } & Citations & Per cent. & Cumulative per cent. \\
\hline 0-5 years & 28 & 12.6 & 12.6 \\
6-10 years & 34 & 15.3 & 27.9 \\
11-15 years & 25 & 11.3 & 39.2 \\
16-20 years & 10 & 4.5 & 43.7 \\
$21-25$ years & 27 & 12.2 & 55.9 \\
26-30 years & 10 & 4.5 & 60.4 \\
31-35 years & 13 & 5.9 & 66.2 \\
36-40 years & 17 & 7.7 & 73.9 \\
41-45 years & 6 & 2.7 & 76.6 \\
46-50 years & 5 & 2.3 & 78.8 \\
51-60 years & 9 & 4.1 & 82.9 \\
61-70 years & 5 & 2.3 & 85.1 \\
71-80 years & 4 & 1.8 & 86.9 \\
81-90 years & 6 & 2.7 & 89.6 \\
91-100 years & 3 & 1.4 & 91.0 \\
101-150 years & 14 & 6.3 & 97.3 \\
151-200 years & 4 & 2.3 & 99.5 \\
201 years or older & 1 & 0.5 & 100.0 \\
Total & $\mathbf{2 2 1}$ & $\mathbf{1 0 0 . 0}$ & \\
\hline Median age = 24 years & \\
Mean age = 36 years & \multicolumn{2}{|}{} \\
Standard deviation = 39 years &
\end{tabular}

It is a curious fact that the median age of articles cited is greater than the average for all documents, and also that the Price's Index for citations of journals is $12.6 \%$, which is less than the average. Since the point of academic journals is to bring about current awareness of

\footnotetext{
${ }^{82}$ Price, 'Citation measures,' pp.10-15.

${ }^{83}$ Price, 'Citation measures,' pp.16-21.
} 
new research, one would expect the Price's Index based solely on citation of them to be higher than one calculated for books - but it is not so. What this seems to indicate is that botanists in fact rely slightly more heavily on monographs for current awareness than on journal articles.

The mean age of cited journal articles and their standard deviation are less than the mean and standard deviation of the ages of all cited documents. This seems to reflect the fact that publishing in journals is a relatively new phenomenon, and that taxonomic botanists continue to cite monographs from a time when botanical journals hardly existed.

Table 8 gives the ages of cited monographs:

Table 8: Age of monographs cited

\begin{tabular}{|c|c|c|c|}
\hline Interval & Citations & Per cent. & Cumulative per cent. \\
\hline $0-5$ years & 30 & 13.5 & 13.5 \\
\hline $6-10$ years & 42 & 18.8 & 32.3 \\
\hline $11-15$ years & 25 & 11.2 & 43.5 \\
\hline $16-20$ years & 23 & 10.3 & 53.8 \\
\hline $21-25$ years & 11 & 4.9 & 58.7 \\
\hline 26-30 years & 13 & 5.8 & 64.6 \\
\hline 31-35 years & 9 & 4.0 & 68.6 \\
\hline $36-40$ years & 4 & 1.8 & 70.4 \\
\hline $41-45$ years & 14 & 6.3 & 76.7 \\
\hline $46-50$ years & 4 & 1.8 & 78.5 \\
\hline $51-60$ years & 10 & 4.5 & 83.0 \\
\hline $61-70$ years & 1 & 0.4 & 83.4 \\
\hline $71-80$ years & 2 & 0.9 & 84.3 \\
\hline $81-90$ years & 2 & 0.9 & 85.2 \\
\hline $91-100$ years & 2 & 0.9 & 86.1 \\
\hline $101-150$ years & 20 & 9.0 & 95.1 \\
\hline $151-200$ years & 6 & 2.2 & 97.3 \\
\hline 201-300 years & 5 & 2.2 & 99.6 \\
\hline 301 years or older & 1 & 0.4 & 100.0 \\
\hline Total & 224 & 100.0 & \\
\hline \multicolumn{4}{|c|}{ Median age $=17$ years } \\
\hline \multicolumn{4}{|c|}{ Mean age $=40$ years } \\
\hline \multicolumn{4}{|c|}{ Standard deviation $=53$ years } \\
\hline
\end{tabular}

As has been noted, the mean age of cited monographs is notably higher than that of cited journals, while the Price's Index and median age are lower. It appears that botanical monographs cite other monographs more intensively than they cite journal articles in what Line called the 'updating' (i.e. current awareness) phase of their useful lives as citable 
documents; references to monographs older than about twenty years drop off more rapidly than references to articles of a similar age; but what Line called 'normal' use of monographs seems to persist for longer. Table 9 gives the average ages of the different kinds of documents cited:

Table 9: Average age of cited documents

\begin{tabular}{|l|r|r|r|}
\hline & Median / years & Mean / years & Standard deviation / years \\
\hline All documents & $21^{*}$ & 38 & 46 \\
Journal articles & 24 & 36 & 39 \\
Monograph books & 17 & 40 & 53 \\
\hline
\end{tabular}

* or 'citing half-life' of source-monographs

Of course, it must be emphasized that this Linean view is only indicated by the present results, and not demonstrated, since this study is synchronous (based on citations made all at the same time) rather than diachronous (based on citations made over several years). It is only by means of a diachronous comparative study of citations to monographs and to journal articles that it can be shown definitively how the use of botanical documents changes over time (see above, I[2.2.2. and I[4.4.4.). 


\subsection{Other results}

It has been possible to glean other results from the data, which may be of some value for managing botanical collections or answering botanical reference queries.

\section{I5.5.1. Countries and languages of publication}

Tables 10 and 11 show the relative importance of different countries in botanical publications.

Table 10: Country of publication of citing monographs

\begin{tabular}{|c|c|c|c|}
\hline Country & Frequency & Per cent. & $\begin{array}{l}\text { Cumulative } \\
\text { per cent. }\end{array}$ \\
\hline USA & 11 & 23.4 & 23.4 \\
\hline Great Britain & 8 & 17.0 & 40.4 \\
\hline Mexico & 4 & 8.5 & 48.9 \\
\hline France & 3 & 6.4 & 55.3 \\
\hline Brazil & 2 & 4.3 & 59.6 \\
\hline China & 2 & 4.3 & 63.8 \\
\hline Spain & 2 & 4.3 & 68.1 \\
\hline Argentina & 1 & 2.1 & 70.2 \\
\hline Austria & 1 & 2.1 & 72.3 \\
\hline Bangladesh & 1 & 2.1 & 74.5 \\
\hline Canada & 1 & 2.1 & 76.6 \\
\hline Germany & 1 & 2.1 & 78.7 \\
\hline India & 1 & 2.1 & 80.8 \\
\hline Iran & 1 & 2.1 & 83.0 \\
\hline Ireland & 1 & 2.1 & 85.1 \\
\hline Italy & 1 & 2.1 & 87.2 \\
\hline Lichtenstein & 1 & 2.1 & 89.4 \\
\hline Romania & 1 & 2.1 & 91.5 \\
\hline Russia & 1 & 2.1 & 93.6 \\
\hline Singapore & 1 & 2.1 & 95.7 \\
\hline Thailand & 1 & 2.1 & 97.9 \\
\hline Ukraine & 1 & 2.1 & 100.0 \\
\hline Total & 47 & 100.0 & \\
\hline
\end{tabular}


Table 11: Country of publication of cited documents

\begin{tabular}{|l|r|r|r|}
\hline & & & Cumulative \\
per cent.
\end{tabular}

The variety of countries of publication is much greater for cited documents than for citing monographs, but this is only to be expected, considering the greater number of cited 
documents. We seem to have another skewed distribution here, similar to the distributions of cited articles among journals and of cited monographs among publishers (see above, 9[5.1-2.). British and American publishers dominate: in both cases these two countries account for nearly half of the publications. It is perhaps the data in table 11 that should attract most interest: this is after all a larger sample and one of documents cited, i.e. documents of value. Here, other European countries with known strengths in botany, as well as India, China, Canada and Mexico, occupy $40 \%$ or so of the cited publications after Britain and the United States - this could be regarded as an approximate second rank of a Bradfordian kind. That Brazil is outside this rank, with only three citations, is a little surprising, considering botanical importance of that country; and it is notable that if the citations of Malaysia and Singapore were combined, the total-9-would put the Malay Peninsula within this notional second rank. The presence of the Ukraine in the second rank is an anomaly.

Tables 12 and 13 show the languages in which the various documents were published:

Table 12: Language of citing monographs

\begin{tabular}{|l|r|r|r|}
\hline & Frequency & Per cent. & Cumulative per cent. \\
\hline English & 30 & 63.8 & 63.8 \\
Spanish & 7 & 14.9 & 78.7 \\
French & 3 & 6.4 & 85.1 \\
Portuguese & 2 & 4.3 & 89.4 \\
Italian & 1 & 2.1 & 91.5 \\
Romanian & 1 & 2.1 & 93.6 \\
Russian & 1 & 2.1 & 95.7 \\
Ukrainian & 1 & 2.1 & 97.8 \\
Persian & 1 & 2.1 & 100.0 \\
Total & $\mathbf{4 7}$ & $\mathbf{1 0 0 . 0}$ & \\
\hline
\end{tabular}


Table 13: Language of cited documents

\begin{tabular}{|l|r|r|r|}
\hline & Frequency & Per cent. & Cumulative per cent. \\
\hline English & 329 & 72.5 & 72.5 \\
French & 37 & 8.1 & 80.6 \\
Spanish & 29 & 6.4 & 87.0 \\
German & 16 & 3.5 & 90.5 \\
Latin & 13 & 2.9 & 93.4 \\
Ukrainian & 9 & 2.0 & 95.4 \\
Italian & 7 & 1.5 & 96.9 \\
Russian & 6 & 1.3 & 98.2 \\
Catalan & 3 & 0.7 & 98.9 \\
Portuguese & 2 & 0.4 & 99.3 \\
Dutch & 1 & 0.2 & 99.6 \\
Greek & 1 & 0.2 & 99.8 \\
Romanian & 1 & 0.2 & 100.0 \\
Total & $\mathbf{4 5 4}$ & $\mathbf{1 0 0 . 0}$ & \\
\hline
\end{tabular}

The predominance of the English language as a vehicle of communication is only to be expected, and is not simply a result of taking the citing monographs from a British library: English is (as Thompson Reuters puts it) "the universal language of science at this time in history" ${ }^{84}$ Similarly, British and American publishers are known to dominate the world publishing market, so their predominance here is not surprising. It is notable that other European languages (especially French and Spanish) are still represented in scholarship: that Spanish is so important shows how much work is still being done in Central and South America. On the other hand, the languages of Africa, India, China and South East Asia are not represented at all, despite the floristic importance of these regions-publications from here tend to be written in English.

\footnotetext{
${ }^{84}$ Thompson Reuters. 'The Thompson Reuters journal selection process'. <http://thompsonreuters.com/products_services/science/free/essays/journal_selection_process/> [2011], [accessed 26.07.2011].
} 


\section{II5.5.2. Important journals for British botanists}

The following table shows all the journals that were cited in botanical monographs published in Great Britain:

Table 14: Journals cited in monographs published in Great Britain

\begin{tabular}{|c|c|c|c|}
\hline Title & Citations & Per cent. & Cumulative per cent. \\
\hline Watsonia & 5 & 16.1 & 16.1 \\
\hline New Phytologist & 4 & 12.9 & 29.0 \\
\hline Journal of Ecology & 3 & 9.7 & 38.7 \\
\hline Kew Bulletin & 3 & 9.7 & 48.4 \\
\hline Botaniska Notiser & 2 & 6.5 & 54.8 \\
\hline Acta Botanica Fennica & 1 & 3.2 & 58.1 \\
\hline Allertonia & 1 & 3.2 & 61.3 \\
\hline $\begin{array}{l}\text { Botanical Journal of the } \\
\text { Linnean Society }\end{array}$ & 1 & 3.2 & 64.5 \\
\hline $\begin{array}{l}\text { Botanische Jahrbücher für } \\
\text { Systematik }\end{array}$ & 1 & 3.2 & 67.7 \\
\hline BSBI News & 1 & 3.2 & 71.0 \\
\hline BSBI Scottish Newsletter & 1 & 3.2 & 74.2 \\
\hline $\begin{array}{l}\text { Canadian Journal of Plant } \\
\text { Science }\end{array}$ & 1 & 3.2 & 77.4 \\
\hline Collectanea Botanica & 1 & 3.2 & 80.6 \\
\hline $\begin{array}{l}\text { Journal of Botany : British and } \\
\text { Foreign }\end{array}$ & 1 & 3.2 & 83.9 \\
\hline $\begin{array}{l}\text { Mitteilungen der botanischen } \\
\text { Staatssammlung München }\end{array}$ & 1 & 3.2 & 87.1 \\
\hline Nordic Journal of Botany & 1 & 3.2 & 90.3 \\
\hline $\begin{array}{l}\text { Notes from the Royal Botanic } \\
\text { Garden, Edinburgh }\end{array}$ & 1 & 3.2 & 93.5 \\
\hline Prosea & 1 & 3.2 & 96.8 \\
\hline Taxon & 1 & 3.2 & 100.0 \\
\hline Total & 31 & 100.0 & \\
\hline
\end{tabular}

Watsonia is now known as the New Journal of Botany, and is the main publication of the BSBI (Botanical Society of the British Isles); Botaniska Notiser has been amalgamated into the Nordic Journal of Botany.

\subsubsection{Citation indexes and taxonomic botany}

It has emerged incidentally from carrying out this study that the taxonomic botany as a discipline is still not served as well as it might be by citation indexes of journal articles. Of the 130 cited journals, only 41 are indexed on the ISI Web of Science, whereas Scopus 
indexes current material in fifty of them, and has more or less substantial back-files for another eight titles. ${ }^{85}$ It is also worth noting that five out of the twelve 'core' journals identified by this study (see above, II5.1.) are not indexed by ISI:

Bulletin de la Société Botanique de France

Kew Bulletin

Novosti sistematiki nizshikh rastenii

Ukrainskii botanichnii zhurnal

Watsonia (i.e. New Journal of Botany).

Similarly, twelve out of the 19 journals cited in British monographs (see above, 915.5.2.) are not indexed by ISI:

Acta Botanica Fennica (which is indexed by Scopus)

Allertonia

Botanische Jahrbücher für Systematik

BSBI News

BSBI Scottish Newsletter

Collectanea Botanica

Journal of Botany : British and Foreign

Kew Bulletin

Mitteilungen der botanischen Staatssammlung München

Notes from the Royal Botanic Gardens, Edinburgh

Prosea

Watsonia (i.e. New Journal of Botany).

${ }^{85}$ ISI WEB OF SCIENCE. <http://apps.isiknowledge.com> [2011], [accessed 20.04.2011].

SCOPUS. <http://www.scopus.com/home.url> [2011], [accessed 20.07.2011]. 


\section{§6. Conclusions}

\subsection{General remarks and recommendations}

There are several conclusions which can be drawn from this study, but all of them must be tentative. The attempt to calculate a kind of Impact Factor of journals based on monographcitations has clearly failed. The reason for this is obvious: the number of monographcitations of each journal has turned out to be very small, and not very variable; in calculating the ten-year impact factor, the only real variable has been the number of articles that each journal has published in the ten-year window, not the number of times that these have been cited. Clearly a much larger body of citations (perhaps ten times as many, or more) would have to be assembled, in order to remedy this problem.

On the other hand, the attempt to create a Bradford-type distribution of the bare frequencies with which journals were cited, has enjoyed some success. Twelve journals have been identified as forming a core of most highly-cited journals. Most of these are indeed already viewed as authoritative in the field, and this is confirmed by the present study.

However, there is certainly room to improve this Bradford distribution. The first problem is that there are twelve more journals that, like Botaniska Notiser, have three citations each, but they have been cut out of the 'core' group simply because of the alphabetical filing of their titles. This seems misleading, and is really another consequence of the small size of the sample used for this study. Secondly, it is quite clear that Novosti sistematiki nizshikh rastenii (Non-vascular Plant Systematics News) and Ukrainskii botanichni zhurnal (Ukrainian Journal of Botany) are not really 'core' journals, and have only appeared here because they were heavily cited by (respectively) the one Russian monograph and the one 
Ukrainian monograph that fell into the sample of citing monographs. Again, the small size of this sample is the cause. A third apparent problem is that Kew Bulletin appears at the top of the Bradford ranking. The Library at the Royal Botanic Gardens has the policy of acquiring copies of all books published by the Gardens; and this, along with the likelihood of institutional self-citation, suggests the possibility of biased results. However, only three of the ten citations of Kew Bulletin are made in books published by the Royal Botanic Gardens, and, if these are discounted, Kew Bulletin is still comfortably inside the top twelve most-cited journals. It is therefore recommended that library collections managers and subject specialists should be aware of the following journals:

American Journal of Botany

Botanical Journal of the Linnean Society

Bulletin de la Société Botanique de France

Canadian Journal of Plant Science

Kew Bulletin

New Phytologist

Systematic Botany

Watsonia (now the New Journal of Botany).

On the assumption that the reader of this study is most concerned with British libraries, the 19 journals cited in British monographs have been specially tabulated. It is clear from this that there is a definite local interest which may need to be served by libraries with botanical readers: three journals are published by the BSBI (the two newsletters and Watsonia/New Journal of Botany), and another three are published by the Linnean Society of London and the Royal Botanic Gardens at Kew and Edinburgh. The BSBI publications in particular publish work on British plant-life, and (after all) British students of botany are likely to be students of British botany. The frequency with which BSBI journals are cited indicates a focus of research, and not merely national prejudice. It is therefore recommended that collections librarians in British libraries should take this into account.

It is arguable - up to a point - that publishers are to monograph books what journals are to journal articles, and so finding out what are the most important book-publishers in a given field should be of interest to librarians (especially to acquisitions librarians). In this respect too, the value of the present study is mainly that it confirms what experienced selectors of botanical monographs already know, that publishers like CUP, Timber Press, Springer, Science Press (Beijing) and the Royal Botanic Gardens, Kew, are among the most important publishers. (Incidentally, in the present sample no monographs published at Kew were cited by other monographs published at Kew.) Also notable is the importance of monographs published by their authors - the difficulty of getting hold of copies of such books is apparently one which acquisitions librarians must still grapple with from time to time when building up good botany collections. 
As with the Bradford distribution of journals, so here, the small size of the sample has allowed some oddities to creep in. For instance, the comparatively minor publishers Efstathiadis and the Succulent Plants Trust were each cited several times in single monographs, in much the same way as the Russian and Ukrainian journals mentioned above. Still, the fact that well-known, important publishers are so well represented, seems to show that the basic method is sound; and a larger sample would probably drive oddities down the ranking.

This study has confirmed and underlined two unsurprising facts about the publications in taxonomic botany: (i) that books are relatively more important than in other sciences, and (ii) that older materials are relatively more important than in other sciences. The discipline places a great deal of value on the oldest work: and it appears that monographs continue to be cited for longer than journal articles (the very oldest book referred to in the present study is over three hundred years old). This is only to be expected, but the present study at least provides some quantitative evidence to justify collections managers in continuing to place emphasis on monographs and on older materials in botany collections. What is unexpected is that monographs are also referred to slightly more intensively than journal articles when they are still very new. In other words, it appears that botanists use monograph books (as well as journal articles) for current awareness purposes. It is recommended that librarians should take this into account: the acquisition of new books must be particularly prompt where the authors have the same interests as local researchers; such books must be processed and catalogued quickly, and displayed prominently; and any current awareness services (such as bibliographies) which subject librarians provide must include new books as well as new journal articles.

The United States and Great Britain have been found to be the most important countries of origin for botanical publications, and English to be the most important language: this reflects the real state of scientific publication across the world, and not an acquisitions policy of the Library at the Royal Botanic Gardens. Sometimes, however, materials are published in other European languages-Spanish is particularly important in new publications. It is therefore recommended that, for small botanical collections, British and American documents in English should be obtained in preference to others: this will give sufficiently good coverage for a small collection. However, for larger collections, librarians must still be ready to acquire materials and to manage collections in botany that include non-Anglophone documents, and to answer reference queries connected with them.

Finally (and as an aside), it appears that taxonomic botany journals are not adequately covered in citation indexes. Scopus seems to have slightly broader coverage than ISI Web of Science, but there are still several journals that are authoritative in the field which neither 
index includes. Garfield and Thompson Reuters have stated the criteria by which journals are selected or rejected by ISI Web of Science, but it is not entirely clear from these statements why journals like New Journal of Botany or Kew Bulletin should be omitted. Perhaps the clearest indication is given in the selection criteria for BIOSIS: "the journal's editorial roster must ... display diversity of institutional affiliation and geographic base" ${ }^{86}$ It may be that the publications of the Royal Botanic Gardens at Kew and at Edinburgh, and those of the BSBI, fail to meet this criterion, since the editorial staff are presumably mostly from the publishing institutions themselves. It is interesting that the Botanical Journal of the Linnean Society is indexed by ISI Web of Science and by Scopus, and that it has been published by Blackwell on behalf of the Society since 2001. At any rate, taxonomic botanists who wish to use ISI or Scopus to assess the impact of their own research should beware the error that could result — and librarians who assist researchers with bibliometric self-assessment should also be aware of this.

\section{I6.2. Further investigation}

This study is really only a first step towards a better understanding of the bibliometrics of taxonomic botany. There are ways in which it could be improved and extended, some of which are more practicable than others.

Firstly, any future study of citations from monographs should be carried out on a much larger scale, so that the general patterns shown in this study can be better investigated and worked out in more detail, and so that some of its errors and oddities can be corrected. A larger study would also make it possible to investigate the impact of journals on monographs - which had been one of the main objectives of the present investigation.

Secondly, a systematic comparison of citations from journal articles should be made with those from monographs: in other words, an orthodox citation-study based on existing citation indexes should also be carried out. It appears from the present study that monographs and journal articles are about as important as each other in the publication of botanical research, so this should be reflected in future work. Other forms of publication, though comparatively minor, should not be neglected: doctoral theses often contain revisions

\footnotetext{
${ }^{86}$ Thompson Reuters. 'Journal evaluation and source coverage policies for BIOSIS products.' <http://thomsonreuters.com/products_services/science/free/essays/journal_evaluation_biosis/> [2011], [accessed 26.07.2011].

Thompson Reuters 'The Thompson Reuters journal selection process.'

<http://thompsonreuters.com/products_services/science/free/essays/journal_selection_process/> [2011], [accessed 26.07.2011].

Garfield, Eugene. 'How ISI selects journals for coverage : quantitative and qualitative considerations.' Current contents [online], 1990, 22, pp.185-193.

<http://www.garfield.library.upenn.edu/essays/v13p185y1990.pdf >, [accessed 26.07.2011].
} 
of particular taxa, and what role they play in the literature of botany requires further investigation.

Thirdly (and perhaps least practicably), some effort should be made to carry out a diachronous study of the citation of botanical monographs. Careful investigation could be made of those monographs that are indexed by ISI Web of Science, to see whether a sample representative of the literature as a whole could be obtained. This, alongside a diachronous study of citations of journal articles, would allow a much better understanding of the overall shape of taxonomic botany as a discipline and how it develops over time, as expressed in the pattern of its publications. 


\section{§7. Bibliography}

AL-QALLAF, Charlene L. 'A bibliometric analysis of the Punica grantum [sic] L. literature.' Malaysian journal of library and information science [online], 2009, 14 (1), pp.83-103. <http://majlis.fsktm.um.edu.my/document.aspx?FileName=731.pdf>, [accessed 01.02.2011].

ANDRÉS, Ana. Measuring academic research: how to undertake a bibliometric study. Oxford : Chandos, 2009.

BAIRD, Laura M., and OPPENHEIM, Charles. 'Do citations matter?' Journal of information science [online], 1994, 20 (1), pp.2-15. 〈http://online.sagepub.com>, [accessed 07.04.2011].

BELL, Judith. Doing your research project: a guide for first-time researchers in education and social science. $3^{\text {rd }}$ ed. Buckingham : Open University Press, 1999.

BENSMAN, Stephen J. 'Urquhart's and Garfield's laws: the British controversy over their validity.' Journal of the American Society for Information Science and Technology [online], 2001, 52 (9), pp.714-724. <http://web.ebscohost.com>, [accessed 13.04.2011].

BISWAS, Bidhan Ch., ROY, Amit, and SEN, B. K. 'Economic Botany: a bibliometric study.' Malaysian journal of library and information science [online], 2007, 12 (1), pp.22-33. <http://majlis.fsktm.um.edu.my/document.aspx?FileName=513.pdf>, [accessed 01.02.2011].

BORGMAN, Christine L. (ed.). Scholarly communication and bibliometrics. Newbury Park, California : SAGE, 1990. 
BORNMANN, Lutz, and DANIEL, Hans-Dieter. 'What do citation counts measure? A review of studies on citing behavior [sic].' Journal of Documentation [online], 2008, 64 (1), pp.45-80. <http://www.emeraldinsight.com>, [accessed 08.04.2011].

BOWMAN, Michael. 'Format citation patterns and their implications for collection development in research libraries.' Collection building [online], 1991, 11 (1), pp.2-8. < http://www.emeraldinsight.com >, [accessed 13.04.2011].

BRADFORD, S. C. Documentation. $2^{\text {nd }}$ ed. reprint. [Ann Arbor, Michigan] : University Microfilms, 1971.

BRAUN, Tibor, GLÄNZEL, Wolfgang, and SCHUBERT, András. 'A Hirsch-type index for journals.' Scientometrics [online], 2006, 69 (1), pp.169-173. <http://www.springerlink.com>, [accessed 13.04.2011].

BRYMAN, Alan. Social research methods. $3^{\text {rd }}$ ed. Oxford : Oxford University Press, 2008. CORBY, Katherine. 'Constructing core journal lists: mixing science and alchemy.' Portal: libraries and the academy [online], 2003, 3 (2), pp.207-217. < http://muse.jhu.ed >, [accessed 12.04.2011].

CRONIN, Blaise. The Citation process: the role and significance of citation in scientific communications. London : Taylor Graham, 1984.

— and ATKINS, Helen Barsky (edd.). The Web of knowledge: a Festschrift in honor [sic] of Eugene Garfield. Medford, N.J. : ASIS, 2000

— SNYDER, Herbert, and ATKINS, Helen. 'Comparative citation rankings of authors in monographic and journal literature.' Journal of documentation [online], 1997, 53 (3), pp.263-273. <http://www.emeraldinsight.com>, [accessed 15.04.2011].

CULLARS, John M. 'Characteristics of the monographic literature of British and American literary studies.' College and research libraries, 1985, 46 (5), pp.511-522.

—. 'Characteristics of the monographic scholarship of foreign literary studies by native speakers of English.' College and research libraries, 1988, 49 (2), pp.157-170.

—. 'Citation characteristics of English-language monographs in philosophy.' Library and information science research [online], 1998, 20 (1), pp.41-68. <http://www.sciencedirect.com>, [accessed 02.02.2011].

- ' 'Citation characteristics of French and German fine arts monographs.' Library quarterly, 1996, 66 (2), pp.138-160.

—. 'Citation characteristics of Italian and Spanish literary monographs.' Library quarterly, 1990, 60 (4), pp.337-356. 
—. 'Citation characteristics of monographs in the fine arts.' Library quarterly, 1992, 62 (3), pp.325-342.

DE BELLIS, Nicola. Bibliometrics and citation analysis: from the Science Citation Index to cybermetrics. Lanham, Maryland : Scarecrow Press, 2009.

DELENDICK, Thomas J. 'Citation analysis of the literature of systematic botany: a preliminary survey.' Journal of the American Society for Information Science [online], 1990, 41 (7), pp.535-543. <http://web.ebscohost.com>, [accessed 31.01.2011].

DONOHUE, Joseph C. Understanding scientific literature: a bibliometric approach. Cambridge, Massachusetts : MIT Press, 1973.

EGGHE, Leo. 'Dynamic $h$-index: the Hirsch index in function of time.' Journal of the American Society for Information Science and Technology [online], 2006, 58 (3), pp.452-454. <http://onlinelibrary.wiley.com/>, [accessed 13.04.2011].

—. 'Theory and practise [sic] of the g-index.' Scientometrics [online], 2006, 69 (1), pp.131-152. <http://www.springerlink.com>, [accessed 13.04.2011].

ERFTEMEIJER, P. L. A., SEMESI, A. K., OCHIENG, C. A. 'Challenges for marine botanical research in East Africa: results of a bibliometric survey.' [Abstract only.] South African journal of botany [online], 2001, 67 (3), pp.411-419. <http://ajol.info/index.php/sajb/article/view/20456/0>, [accessed 01.02.2011].

EURIM II: A EUROPEAN CONFERENCE ON THE APPLICATION OF RESEARCH IN INFORMATION SERVICES AND LIBRARIES. London : Aslib, 1977.

FAIRTHORNE, Robert A. 'Empirical hyperbolic distribution (Bradford-Zipf-Mandelbrot) for bibliometric description and prediction.' Journal of documentation [online], 2005, 61 (2), pp.171-193. <http://www.emeraldinsight.com>, [accessed 12.04.2011]. (Originally published: Journal of documentation, 1969, 25 (4), pp.319-343.)

GARFIELD, Eugene. 'The 250 most-cited primary authors, 1961-1975. Part 1, How the names were selected.' In: Essays of an information scientist, vol.3, pp.326-326.

—. The 300 most-cited authors, 1961-1976, including co-authors at last. 1, How the names were selected.' In: Essays of an information scientist, vol.3, pp.538-550.

—. 'Citation analysis as a tool in journal evaluation.' Science [online], 1972, 178 (4060), pp.471-479. <http://www.sciencemag.org/content/178/4060/471.full.pdf?sid=59524e7b7983-42c8-9ea2-caa67b0a3c6b>, [accessed 02.02.2011].

- Citation indexing: its theory and application in science, technology and humanities. New York : John Wiley and Sons, 1979. 
—. 'Dispelling some common myths about journal citation impacts.' Scientist [online], 1997, 11 (3). <http://www.the-scientist.com>, [accessed 06.06.2011].

—. Essays of an information scientist. Philadelphia : ISI Press, 1977-1981.

- 'The Gordian Knot of journal coverage: why we can't put all the journals you want into the Current Contents edition you read.' In: Essays of an information scientist, vol.3, pp.452-454.

—. 'Highly cited articles from plant physiology journals.' In: Essays of an information scientist, vol.2, pp.210-215.

—. 'Highly cited botanical articles from botanical and other journals.' In: Essays of an information scientist, vol.2, pp.216-220.

_ _ 'How ISI selects journals for coverage : quantitative and qualitative considerations.' Current contents [online], 1990, 22, pp.185-193.

<http://www.garfield.library.upenn.edu/essays/v13p185y1990.pdf >, [accessed 26.07.2011].

—. 'Is citation frequency a valid criterion for selecting journals?' Current contents [online], 1972, 13. <http://www.garfield.library.upenn.edu>, [accessed 13.04.2011].

—. 'Journal citation studies. 18, Highly cited botany journals.' In: Essays of an information scientist, vol.2, pp.205-209.

—. 'Journal citation studies. 33, Botany journals. Part 1, What they cite and what cites them.' In: Essays of an information scientist, vol.4, pp.555-562.

—. 'Journal citation studies. 33, Botany journals. Part 2, Growth of botanical literature and highly-cited items.' In: Essays of an information scientist, vol.4, pp.563-573.

—. 'Lifetime citation rates.' In: Essays of an information scientist, vol.4, pp.355-358.

—. 'Significant journals of science.' In: Essays of an information scientist, vol.3, pp.132-146.

- and SHER, I. H. 'New factors in the evaluation of scientific literature through citation indexing.' American documentation [online], 1963, 14 (3), pp.195-201. <http://web.ebscohost.com>, [accessed 18.04.2011].

GEORGAS, Helen, and CULLARS, John. 'A citation study of the characteristics of the linguistics literature.' College and research libraries, 2005, 66 (6), pp.496-516. 
GLÄNZEL, Wolfgang, and MOED, Henk F. 'Journal impact measures in bibliometric research.' Scientometrics [online], 2002, 53 (2), pp.171-193.

<http://www.springerlink.com>, [accessed 13.04.2011].

GOOGLE SCHOLAR. <http://scholar.google.co.uk> [2011], [accessed 03.02.2011].

GRIFFITHS, Mark. 'Kew's Library is an open book.' Country life, 2011, 205 (9), p.121.

HIRSCH, J. E. 'An Index to quantify an individual's scientific output.' Proceedings of the National Academy of Sciences of the United States of America [online], 2005, 102 (46), pp.16569-16572. <http://www.ncbi.nlm.nih.gov/pmc/>, [accessed 12.04.2011].

HIRST, Graeme. 'Discipline Impact Factors: a method for determining core journal lists.' Journal of the American Society for Information Science [online], 1978, 29 (4), pp.171172. <http://web.ebscohost.com>, [accessed 13.04.2011].

INTERNATIONAL CODE OF BOTANICAL NOMENCLATURE [online]. <http://ibot.sav.sk/icbn/main.htm> [2011], [accessed 04.04.2011].

INTERNATIONAL PLANT NAMES INDEX [online]. <http://www.ipni.org/index.html> [2011], [accessed 01.02.2011].

ISI WEB OF SCIENCE. <http://apps.isiknowledge.com> [2011], [accessed 20.04.2011].

JOHNSON, Peggy. Fundamentals of collection development and management [online]. $2^{\text {nd }}$ ed. Chicago : ALA, 2009. <http://opac.lboro.ac.uk>, [accessed 17.05.2011].

LINDHOLM-ROMANTSCHUK, Ylva, and WARNER, Julian. 'The Role of monographs in scholarly communication: an empirical study of philosophy, sociology and economics.' Journal of documentation [online], 1996, 52 (4), pp.389-404.

<http://www.emeraldinsight.com>, [accessed 15.04.2011].

LINE, Maurice B. 'The Influence of the type of sources used on the results of citation analysis.' Journal of documentation [online], 1979, 35 (4), pp.365-284.

<http://www.emeraldinsight.com>, [12.04.2011].

—. 'On the Irrelevance of citation analyses to practical librarianship.' In: EURIM II, pp.51-56.

—. The Structure of social science literature as shown by citations. [Bath] : Bath University, 1979. - and SANDISON, A. ' 'Obsolescence' and changes in the use of literature over time.' Journal of documentation [online], 1974, 30 (3), pp.283-350. <http://www.emeraldinsight.com>, [accessed 02.02.2011]. 
— and —_. 'Practical interpretation of citation and library use studies.' College and research libraries, 1975, 36 (5), pp.393-396.

LIU Meng Xiong. 'The Complexities of citation practice: a review of citation-studies.' Journal of documentation [online], 1993, 49 (4), pp.370-408.

<http://www.emeraldinsight.com>, [accessed 08.04.2011].

LOVEGROVE, Barry G., and JOHNSON, Steven D. 'Assessment of research performance in biology: how well do peer-review and bibliometry correlate?' [Abstract only.] BioScience [online], 2008, 58 (2), pp.160-164. <http://www.bioone.org>, [accessed 02.02.2011].

MACROBERTS, M. H., and MACROBERTS, B.R. 'Citation content analysis of a botany journal.' Journal of the American Society for Information Science [online], 1997, 48 (3), pp.274-275. <http://web.ebscohost.com>, [accessed 01.02.2011].

and _ _ 'Problems of citation analysis: a critical review.' Journal of the American Society for Information Science [online], 1989, 40 (5), pp.342-349. <http://web.ebscohost.com>, [accessed 12.04.2011].

MCDONALD, John D. 'Understanding journal usage : a statistical analysis of citation and use.' Journal of the American Society of Information Science and Technology [online], 2007, 58 (1), pp.39-50. <http://web.ebscohost.com>, [accessed 16.06.2011].

MEADOWS, A. J. Communicating research. San Diego : Academic Press, 1998.

—. 'The Growth of journal literature: a historical perspective.' In: CRONIN and ATKINS, Web of knowledge, pp.87-108.

'A Practical line in bibliometrics.' Interlending and document supply [online], 2005, 33 (2), pp.90-94. <http://www.emeraldinsight.com>, [accessed 14.04.2011].

MOED, Henk F. Citation analysis in research evaluation. Dordrecht : Springer, 2005.

—, LEEUWEN, Th. N. van, REEDIJK, J. 'A New classification system to describe the ageing of scientific journals and their impact factors.' Journal of documentation [online], 1998, 54 (4), pp.387-419. <http://www.emeraldinsight.com>, [accessed 16.06.2011].

MORRIS, Anne. SPSS for information science : an introductory guide to SPSS.

Loughborough : Loughborough University, 2011.

MORTON, A. G. History of botanical science: an account of the development of botany from ancient times to the present day. London : Academic Press, 1981.

NATIONAL HERITAGE ACT (1983) [online].

<http://www.legislation.gov.uk/ukpga/1983/47/contents> [2011], [accessed 30.01.2011]. 
NELSON, Carnot E., and POLLOCK, Donald K. (edd.). Communication among scientists and engineers. Lexington, Massachusetts : D.C. Heath, 1970.

NICHOLAS, David, and HERMAN, Eti. Assessing information needs in the age of the digital consumer. $3^{\text {rd }}$ ed. London : Routledge, 2009, pp.150-152.

NICHOLAS, David, and RITCHIE, Maureen. Literature and bibliometrics. London : Clive Bingley, 1978.

— - _ and RITCHIE, Adrian. Literature usage and interrelationships in the social sciences as shown by citations in monographs. [London] : Polytechnic of North London, 1978.

NICOLAISEN, Jeppe, and HJøRLAND, Birger. 'Practical potentials of Bradford's law: a critical examination of the received view.' Journal of documentation [online], 2007, 63 (3), pp.359-377. <http://www.emeraldinsight.com>, [accessed 12.04.2011].

NORDSTROM, L. O. 'Applied versus basic science in the literature of plant biology: a bibliometric perspective.' Scientometrics [online], 1987, 12 (5-6), pp.381-393. <http://www.springerlink.com>, [accessed 14.04.2011].

OPPENHEIM, Charles, and RENN, Susan P. 'Highly cited old papers and the reasons why they continue to be cited.' Journal of the American Society for Information Science [online], 1978, 29 (5), pp.225-231. < http://web.ebscohost.com>, [accessed 12.04.2011].

PERSSON, Olle. 'All author citations versus first author citations.' Scientometrics [online], 2001, 50 (2), pp.339-344. <http://www.springerlink.com>, [accessed 13.06.2011].

PRICE, Derek J. de Solla. 'Citation measures of hard science, soft science, technology, and nonscience.' In: NELSON and POLLOCK, Communication, pp.3-22.

—. Little science, big science. $2^{\text {nd }}$ ed. New York : Columbia University Press, 1965.

—. 'Networks of scientific papers.' Science [online], 1965, 149 (3683), pp.510-515. <http://www.sciencemag.org>, [accessed 01.02.2011].

PRITCHARD, Alan. 'Statistical bibliography or bibliometrics?' Journal of documentation [online], 1969, 25 (4), pp.348-349. <http://www.emeraldinsight.com>, [accessed 12.04.2011].

RAAN, Anthony F. J. van. 'Fatal attraction: conceptual and methodological problems in the ranking of universities by bibliometric methods.' Scientometrics [online], 2005, 62 (1), pp.133-143. <http://www.springerlink.com>, [accessed 11.04.2011].

RANDOM.ORG. <http://www.random.org> [2011], [accessed 13.06.2011]. 
ROYAL BOTANIC GARDENS, KEW. LIBRARY, ART AND ARCHIVES [website of]. <http://www.kew.org/library/index.html> [2011], [accessed 06.06.2011].

SCOPUS. <http://www.scopus.com/home.url> [2011], [accessed 20.07.2011].

STEVENS, Neil E. 'The Fad as a factor in botanical publications.' Science [online], 1932, 75 (1950), pp.499-504. <http://www.sciencemag.org>, [accessed 12.04.2011].

TANG Rong. 'Citation characteristics and intellectual acceptance of scholarly monographs.' College and research libraries [online], 2008, 69 (4), pp.356-369. 〈http://crl.acrl.org>, [accessed 11.04.2011].

THOMPSON REUTERS. 'Journal evaluation and source coverage policies for BIOSIS products.'

<http://thomsonreuters.com/products_services/science/free/essays/journal_evaluation_bio sis/> [2011], [accessed 26.07.2011].

—. 'The Thompson Reuters journal selection process.' <http://thompsonreuters.com/products_services/science/free/essays/journal_selection_pro cess/> [2011], [accessed 26.07.2011].

VINKLER, Péter. The Evaluation of research by scientometric indicators. Oxford : Chandos, 2010.

WALLACE, Danny P. 'A Solution in search of a problem: bibliometrics and libraries.' Library journal [online], 1987, 112 (8), pp.43-47. < http://web.ebscohost.com >, [accessed 14.04.2011]. 


\section{Index}

Adanson, Michel, 2

ageing, bibliometric, 12-14, 15

botany, 20, 25, 34-38, 47

Al-Qallaf, Charlene L., 18, 50

Andrés, Ana, 5, 7, 9, 13, 14, 24, 29, 50

Atkins, Helen Barsky, 16, 51

Baird, Laura M., 9, 50

Bell, Judith, 50

Bensman, Stephen J., 11, 50

Biswas, Bidhan Ch., 18, 50

books. See monographs

Borgman, Christine L., 7, 50

Bornmann, Lutz, 8, 51

botany

bibliometric studies, 17-19

history, 1-2

scientific method, 2-3

Bowman, Michael, 51

Bradford, S. C., 5, 10, 12, 22, 51

botany journals, 24, 29-31, 41, 45-46

Braun, Tibor, 15, 51

Bryman, Alan, 51

Cato, 1

citation indexing, 6, 16, 43-44, 47

citations

internal, 21-22

meaning, 7-9

monographs, 15, 16-17, 21

subject-relevance, $6,8,10$

Columella, 1

Corby, Katherine, 10, 12, 51

core journals, 5, 10-12

botany, 20, 24, 26-31, 43, 45-46

countries of publication, 39-41, 47

Great Britain, 43

Cronin, Blaise, 8, 16, 51

Cullars, John M., 17, 51-52, 53

sampling method, 22, 23, 26

current awareness, 37, 47

Daniel, Hans-Dieter, 8, 51

De Bellis, Nicola, 9, 11, 13, 14, 52

Delendick, Thomas J., 19, 22, 52

Dioscorides, 1

Donohue, Joseph C., 52

Egghe, Leo, 7, 52
Erftemeijer, P. L. A., 17, 52

Fairthorne, Robert A., 5, 52

Garfield, Eugene, 48, 52-53

botany journals, $18-19$

citations, 6,8

Impact Factor, 10, 14, 24

Georgas, Helen, 53

g-index, 7

Glänzel, Wolfgang, 14, 15, 51, 54

Google Scholar, 22, 54

Griffiths, Mark, 22, 54

half-life, bibliometric, 13, 14 monographs, 17, 25, 35, 38

Herman, Eti, 10, 56

$h$-index, 7,14

Hirsch, J. E., 7, 54

Hirst, Graeme, 11, 54

Hjørland, Birger, 12, 56

ICBN (International Code of Botanical Nomenclature), 3, 54

immediacy, bibliometric, 12, 14

Impact Factor

botany journals, 18, 26-28

formula, $6-7,14,24$

library uses, 14

monographs, 24, 26-28, 45

scientific disciplines, 16

IPNI (International Plant Names Index), 22, 54

ISI Web of Science, 16, 21, 22, 24, 54

botany journals, 18-19, 28, 44, 48

Johnson, Peggy, 10, 54

Johnson, Steven D., 17, 55

journals. See core journals; Impact Factor

Jussieu, Antoine Laurent de, 2

languages of publication, 41-42, 47

laws, bibliometric, 5

Leeuwen, Th. N. van, 13, 55

libraries and bibliometrics, 9-15, 19, 20, 4548

Lindholm-Romantschuk, Ylva, 16, 17, 54

Line, Maurice B., 5, 16, 18, 54-55

bibliometrics in libraries, 9, 11, 13 
Linnaeus, Carl, 2

Liu Meng Xiong, 8, 55

Lotka, A. J., 5

Lovegrove, Barry G., 17, 55

Macroberts, B. R., 8, 18, 55

Macroberts, M. H., 8, 18, 55

McDonald, John D., 10, 55

Meadows, A. J., 9, 55

Moed, Henk F., 9, 13, 14, 54, 55

monographs, 16-17

botanical, 3, 20, 21, 25, 33, 47

Impact Factor, 24, 26-28, 45

Morris, Anne, 55

Morton, A. G., 2, 55

National Heritage Act (1983), 22, 55

Nelson, Carnot E., 6, 56

Nicholas, David, 5, 10, 22, 23, 56

Nicolaisen, Jeppe, 12, 56

Nordstrom, L. O., 19, 56

obsolescence, bibliometric, 12-14

Ochieng, C. A., 17, 52

Oppenheim, Charles, 9, 14, 15, 50, 56

Persson, Olle, 24, 56

Pollock, Donald K., 6, 56

Price, Derek J. de Solla, 6, 56-57

botany, 18, 36

research front, 3, 12-13, 15

Price's Index, 12, 15, 34-38

Pritchard, Alan, 56

publishers of monographs, 20, 25, 32, 41, 46

Raan, A. F. J. van, 9, 56

recommendations

for further study, 48-49 for librarians, 45-48

Reedijk, J., 13, 55

Renn, Susan P., 14, 15, 56

research front, 3, 12-13, 15

Ritchie, Adrian, 5, 23, 56

Ritchie, Maureen, 5, 10, 22, 23, 56

Roy, Amit, 18, 50

Royal Botanic Gardens, Kew. Library, 22, 46, 57

sampling, 22-23, 26, 45

Sandison, A., 9, 11, 13, 18, 54

scattering, bibliometric, 5, 10-12, 29-31, 4546

Schubert, András, 15, 51

Science Citation Index. See ISI Web of Science

scientific disciplines bibliometrics, 15-16, 18

Scopus, 44, 57

Semesi, A. K., 17, 52

Sen, B. K., 18, 50

Sher, I. H., 6, 8

skewed statistical distributions, 5, 32, 34-38, 41, See also Bradford, S. C.

Snyder, Herbert, 16, 51

Stevens, Neil E., 57

Tang Rong, 17, 57

Theophrastus, 1

Thompson Reuters, 16, 19, 42, 48, 57, See also ISI Web of Science

Vinkler, Péter, 7, 57

Wallace, Danny P., 10, 57

Warner, Julian, 16, 17, 54 